\title{
Sediment Budget in the Taiwan Strait with High Fluvial Sediment Inputs from Mountainous Rivers: New Observations and Synthesis
}

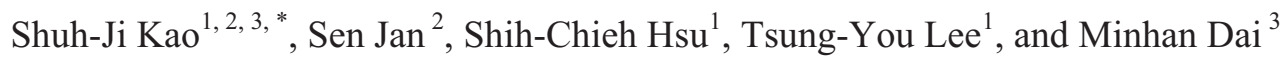 \\ ${ }^{1}$ Research Center for Environmental Changes, Academia Sinica, Taipei, Taiwan, ROC \\ ${ }^{2}$ Institute of Hydrological Sciences, National Central University, Chung-Li, Taiwan, ROC \\ ${ }^{3}$ State Key Laboratory of Marine Environmental Science, Xiamen University, Xiamen, China
}

Received 29 March 2007, accepted 12 November 2007

\begin{abstract}
The shallow Taiwan Strait at the southern opening of the East China Sea (ECS) receives abundant sediments from turbid mountainous rivers in Taiwan. The volume of sediment is among the highest sediment yields on the global surface. This large amount of sediment discharged from modern Taiwan (range: $175-380 \mathrm{Mt} \mathrm{y}^{-1}$ based on 50-yr data) is comparable to that discharged from Changjaing (500 Mt $\mathrm{y}^{-1}$-decreasing in recent decades), underscoring the importance of sediment budget in the Taiwan Strait and sediment flux from Taiwan into the ECS. We documented fluvial mud and sand concentrations during flash flooding with our observations indicating that fluvial materials in Taiwan's rivers are chiefly composed of mud (> $70 \%$ and up to $98 \%$ ). By contrast, sand fraction dominates (> $85 \%$ for most stations) surface sediments in the Taiwan Strait. Super typhoon Herb alone delivered $130 \mathrm{Mt}$ of sediments from Choshui, the largest river in Taiwan, yet only insignificant amounts of mud were found at the river mouth six months later. The actions of waves, tides, and currents apparently prevent the deposition of fine grained sediments. Assuming sand occupied 30\% (the maximum) of the $60 \mathrm{Mt} \mathrm{y}^{-1}$ total sediment input from major western Taiwanese rivers, our annual budget estimate shows that the amount of sand input $\left(18 \pm 5 \mathrm{Mt}^{-1}\right)$ is comparable to the burial output of sand $\left(12 \pm 10 \mathrm{Mt}^{-1}\right)$. However, mud burial $\left(6 \pm 5 \mathrm{Mt} \mathrm{y}^{-1}\right)$ in the strait is far below the estimated mud input $(42 \pm$ $\left.11 \mathrm{Mt}^{-1}\right)$, resulting in a significant shortfall. Hydrodynamic conditions were synthesized to explain the distribution pattern of limited mud patches in the strait and to reveal potential pathways by which fine-grain sediment transportation takes place in the seas surrounding Taiwan. A significant shortfall in the mud budget in the Taiwan Strait suggests that $\sim 85 \%$ of the fluvial mud left the strait. Alternatively, the 50-year modern sediment flux data used in this study reflects exacerbated sediment flux due to human activity and is possibly too high to represent loads during pre-Anthropocene. Additional studies are needed to explore the flux and fate of mud in and surrounding Taiwan over a longer time scale.
\end{abstract}

Key words: Mud, River, Sediment, Sedimentation rate, Taiwan Strait

Citation: Kao, S. J., S. Jan, S. C. Hsu, T. Y. Lee, and M. Dai, 2008: Sediment budget in the Taiwan Strait with high fluvial sediment inputs from mountainous rivers: New observations and synthesis. Terr. Atmos. Ocean. Sci., 19, 525-546, doi: 10.3319/TAO.2008.19.5.525(Oc)

\section{INTRODUCTION}

More than $90 \%$ of world riverine sediments are deposited on the continental margin; allowing this zone to play a key role in linking the terrestrial and oceanic carbon cycles (Thomas et al. 2004; Deng et al. 2006). The East China Sea (ECS) is the most important marginal sea in the western Pacific as it is the interface between the world's largest continent (Asia-Europe) and the Pacific Ocean (Fig. 1). Approximately $10 \%$ of world's fluvial sediments

* Corresponding author

E-mail:sjkao@gate.sinica.edu.tw are delivered to the ECS from two large rivers, i.e., Changjiang and Huanghe (Milliman and Meade 1983). In addition, the annual sediment output from Taiwanese rivers is $\sim 184$ to $380 \mathrm{Mt} \mathrm{y}^{-1}$ (Dadson et al. 2003; Kao et al. 2005), which is comparable to the sediment flux from the largest river, Changjiang, in China (500 Mt $\mathrm{y}^{-1}$; Milliman et al. 1985), particularly when Changjiang's and Huanghe's sediment loads are both decreasing (currently $200 \mathrm{Mt} \mathrm{y}^{-1}$ for

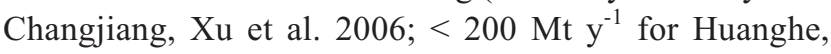
Wang et al. 2007).

Moreover, such island-wide high erosion might have 
(a)

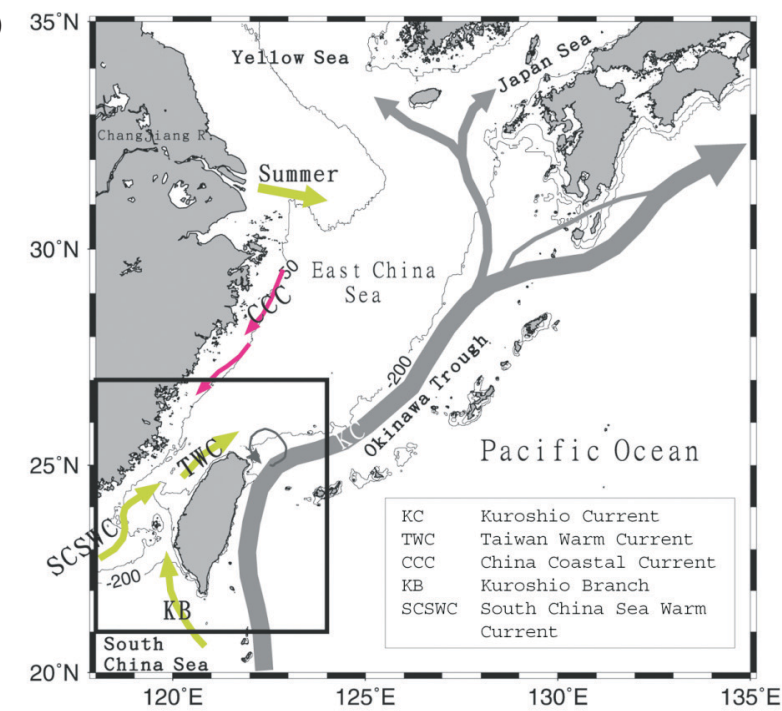

(b)

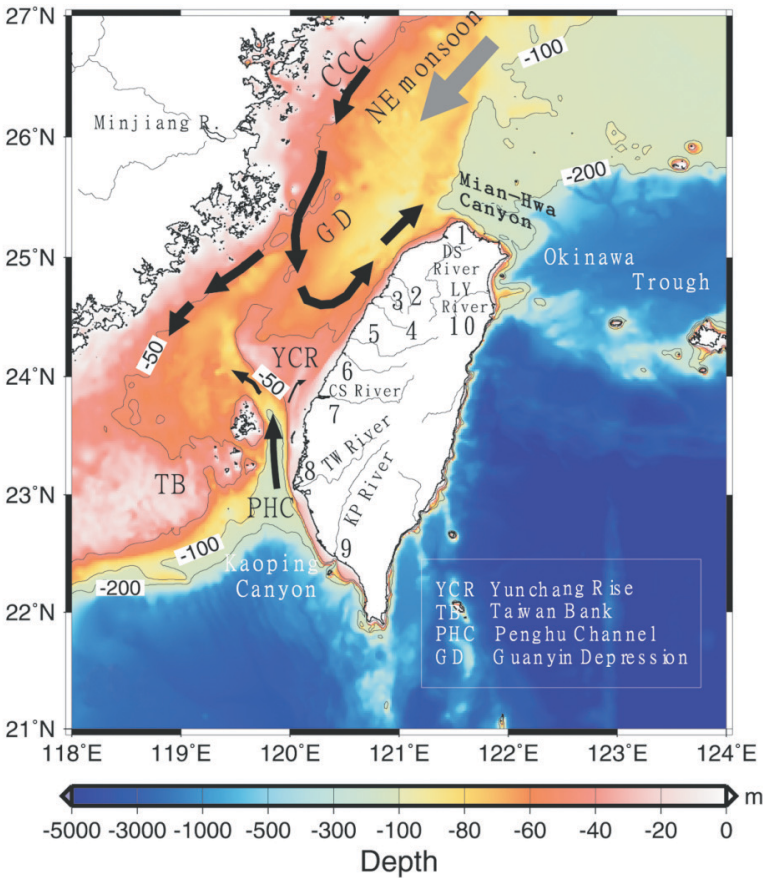

Fig. 1. (a) Location map showing the Taiwan Strait and the adjacent ocean/seas surrounding Taiwan. Red and green arrows represent general flow pattern for winter and summer, respectively. Current abbreviations are shown in the lower right corner. Year-round cyclonic eddy off northeastern Taiwan is also marked. Huanghe River (not shown) locates around $38^{\circ} \mathrm{N}$. (b) Topographic features in the Taiwan Strait, and the locations of the ten primary rivers in this study. Abbreviations for featured topography are shown in the lower right corner. Black and gray arrows represent winter circulation patterns (from Jan et al. 2004) and the direction of the northeasterly monsoon, respectively.

persisted for millions of years (Dadson et al. 2003; Willett et al. 2003). These tremendously high suspended sediment inputs over such a long discharge period from land certainly have significant impacts on elements and carbon biogeochemistry (Lyons et al. 2002) in surrounding shelf areas. For instance, organics can be efficiently trapped in these conti- nental margins due to the rapid sedimentation, which helps transport as well as preserve organic carbon (Kao et al. 2006). In order to complete the sediment and element budget in the ECS, background data on flux, sedimentation processes, and the fate of Taiwan mud are essential.

To determine the sediment load from Taiwan is never an easy task. One of the difficulties in studying sediment flux from small mountainous rivers comes from the fact that they are greatly influenced by aperiodic events. For example, a single typhoon event may account for $>75 \%$ of the total sediment output from these small rivers on an annual basis (Kao and Liu 1996; Kao et al. 2005; Kao and Milliman 2008). This is due to the fact that typhoons generally induce torrential rainfall triggering landslides and the erodible sediments from small mountainous rivers are quickly washed into the sea by flash floods ( 2 - 3 days) with little deposition within the estuarine zone (Liu et al. 2000; Hong et al. 2004), which is in contrast to the scenarios in large rivers, such as in the Changjiang and Huanghe.

In bulk sediment, fine-grained particles are more important carriers for organics and particle-reactive elements due to their high mobility and surface to volume ratios (Keil et al. 1994; Mayer 1994; Hedges and Keil 1995). Thus, it is essential to quantify the size fractionation in floodrelated fluxes for mountainous rivers in order to calculate sediment inputs and understand sediment transport versus biogeochemistry of particle reactive elements in the Taiwan Strait and the ECS. Despite the importance of flood events in flux estimation, very few data on time-series with respect to sediment concentrations are available. Grain size distribution data for suspended sediments are even absent in the literature due to the fact that typhoon floods are often accompanied by extreme weather conditions, which makes field sampling during such events dangerous and extremely difficult. Our field observations during flood periods offer first-hand documentation on grain-size of flood sediments from mountainous rivers in Taiwan. Such field data allow us to estimate coarse- and fine-grained sediment deliveries and thus to evaluate the budget of the two fractions in the strait sediments.

During the past 30 years, increasing studies and investigations on sediment transportation, clay minerals, heavy metals, and sedimentation rate, etc. have been reported. Unfortunately, compilation of the most fundamental information, that is, grain size and sedimentation rate, has not been made in the seas surrounding Taiwan. In this paper, we compiled reported data of sediment grain size and the sedimentation rate surrounding Taiwan, which allows us to map the spatial distribution of mud and further calculate sediment output through burial. Flow field observations and hydrodynamic modeling reported previously was drawn on for discussion and linked qualitatively to spatial distribution of surface sediments and their potential transport pathways in and out of the Taiwan Strait. A significant short- 
fall in the mud budget in the Taiwan Strait suggests that $\sim 85 \%$ of the fluvial mud left the strait; alternatively, modern sediment fluxes obtained by using 50-year data are too high to represent loads during the pre-Anthropocene.

\section{MATERIALS AND METHODS}

\subsection{Study Area}

\subsubsection{Mountainous Rivers in Taiwan}

In recent years, increasing attention has been paid to rivers that drain high-standing Oceania islands due to the paper by Milliman and Syvitski (1992). Numerous Oceania small rivers drain only a few percent (7\%) of the Earth's surface, but may collectively contribute at least $16 \%\left(\sim 2 \mathrm{Pg} \mathrm{yr}^{-1}\right)$ of the world's fluvial suspended sediment flux to the oceans (Syvitski et al. 2005a) albeit with considerable uncertainties due to rapid historical changes in land-use and river diversions during the Anthropocene (Syvitski and Milliman 2007). Given its high tectonic activity, frequent typhoons, highly erodable rocks, high relief (see Table 1; mountain elevations locally $>3000 \mathrm{~m}$ ), and steep gradient, the island of Taiwan (Fig. 1a) is recognized as having particularly high sediment production rates ( $\mathrm{Li}$ 1976; Milliman and Meade 1983), as evidenced by the fact that 7 out of 10 global rivers with the highest sediment yields are Taiwanese (Milliman and Syvitski 1992).

In Taiwan, rainfall and water discharge are highly variable over different time scales. For the ten rivers we are interested in, mean annual rainfall range from 1800 to $3200 \mathrm{~mm} \mathrm{y}^{-1}$ with water runoff depth ranging from 900 to $2400 \mathrm{~mm} \mathrm{y}^{-1}$ (Table 1). However, they exhibit significant seasonal variations. For most parts of Taiwan, 50 to $70 \%$ of the annual total water discharge occurs in the summer. During low-rainfall months mean daily discharge for most rivers is less than 10 $50 \mathrm{~m}^{3} \mathrm{~s}^{-1}$, but can exceed several thousand cubic meters per second during high-rainfall months. The time period for invading typhoons is short and generally lasts less than three days. Thus the use of hourly hydrological data is crucial in sediment flux calculations due to the non-linear response of sediment flux to the water discharge rate (Kao et al. 2005).

During typhoons water discharge increases by $\sim 3$ orders of magnitude within 24 hours and sediment concentrations increase 2 to 4 orders of magnitude resulting in a 6 to 8 order-of-magnitude variability in sediment load (Kao and Liu 2001; Kao et al. 2005; Milliman and Kao 2005). The frequency and intensity of typhoon and typhoon-induced rainfall strongly affect water fluxes, consequently, sediment delivery. Other factors, such as earthquakes, interplay to induce extra sediment output. For instance, sediment loads for the largest river, the Choshui River (River 7 in Fig. 1b) have been particularly high in recent years due to several major typhoons (Herb in 1996 and Toraji and Nari in 2001) and effects of the $1999 \mathrm{M}_{\mathrm{w}}$ 7.6 Chichi earthquake (Dadson et al. 2004). Rains associated with typhoon Toraji (August 2001), the first major typhoon to strike central Taiwan after the Chichi earthquake (October 1999), for example, caused 20000 soil and bedrock landslides in the Choshui watershed alone, resulting in sediment concentrations of $200 \mathrm{~g} \mathrm{~L}^{-1}$ in the river

Table 1. Background information for 10 primary rivers in Taiwan.

\begin{tabular}{|c|c|c|c|c|c|c|c|c|c|}
\hline Code & River Name & $\begin{array}{c}\text { Basin Area } \\
\left(\mathrm{km}^{2}\right)\end{array}$ & Gradient & $\begin{array}{l}\text { Rainfall } \\
\left(\mathrm{mm} \mathrm{y}^{-1}\right)\end{array}$ & $\begin{array}{c}\text { Max } \\
\text { Altitude (m) }\end{array}$ & $\begin{array}{c}\text { Runoff } \\
\left(\mathrm{mm} \mathrm{y}^{-1}\right)\end{array}$ & $\begin{array}{c}\text { Sediment } \\
\text { Load } \\
\left(\mathrm{Mt} \mathrm{y}^{-1}\right)^{*}\end{array}$ & $\begin{array}{l}\text { Upper SS } \\
\text { load } \\
\left(\mathrm{Mt}^{-1}\right)^{* \#}\end{array}$ & $\begin{array}{c}\text { Lower SS } \\
\text { load } \\
\left(\mathrm{Mt} \mathrm{y}^{-1}\right)^{* \#}\end{array}$ \\
\hline 1 & Tanshui & 2725 & $1 / 45$ & 3001 & 3529 & 2086 & 2.3 & 2.9 & 1.9 \\
\hline 2 & Touchien & 566 & $1 / 190$ & 2237 & 2233 & 1370 & 1.1 & 1.2 & 0.7 \\
\hline 3 & Houlung & 536 & $1 / 160$ & 1766 & 2580 & 1328 & 1.7 & 2.3 & 1.3 \\
\hline 4 & Taan & 758 & $1 / 75$ & 2287 & 3296 & 1504 & 4.0 & 4.7 & 3.0 \\
\hline 5 & Tachia & 1235 & $1 / 60$ & 2155 & 3639 & 1999 & 0.5 & 0.6 & 0.2 \\
\hline 6 & $\mathrm{Wu}$ & 2025 & $1 / 92$ & 1755 & 2596 & 1824 & 5.2 & 6.1 & 4.2 \\
\hline 7 & Choshui & 3155 & $1 / 190$ & 2220 & 3416 & 1234 & 37.6 & 41.0 & 29.5 \\
\hline 8 & Tsengwen & 1175 & $1 / 200$ & 2303 & 2440 & 920 & 12.4 & 16.4 & 8.5 \\
\hline 9 & Kaoping & 3256 & $1 / 150$ & 2526 & 3997 & 2389 & 21.2 & 26.5 & 17.8 \\
\hline 10 & Lanyang & 978 & $1 / 55$ & 3191 & 3535 & 2397 & 6.5 & 7.8 & 4.6 \\
\hline \multicolumn{7}{|c|}{ Summarized total sediment load from River 1 through River 7 : } & 52.5 & 58.8 & 40.8 \\
\hline
\end{tabular}

* Numbers related to sediment loads are obtained following the method published by Kao et al. (2005).

\# Upper SS load, which represents the upper value for long-term annual mean sediment load, is derived by considering the negative residuals in rating curve calculation (see details in Kao et al. 2005). Similarly, lower SS load considers positive residuals in calculation. 
and total sediment transport of $>200 \mathrm{Mt}$ in just three days (Dadson et al. 2004). During the six-year period between 1996 and 2001, the Choshui discharged $~ 500$ Mt of sediment, even greater than the annual sediment load from the Changjiang River (Kao and Milliman 2008).

\subsubsection{Taiwan Strait}

The Taiwan Strait (TS), bounded by the China coast to the west and the island of Taiwan to the east (Fig. 1a), is a relatively shallow channel (180 km wide, $350 \mathrm{~km}$ long and $60 \mathrm{~m}$ deep on average) receiving abundant sediment inputs from Taiwan rivers (Fig. 1b). Four topographic features, namely, the Penghu Channel (PHC), Yunchang Rise (YCR), Taiwan Bank (TB) and Guanyin Depression (GD) characterize the shallow Taiwan Strait (Fig. 1b). The Yunchang Rise is located at the eastern central part of the strait. The Taiwan Bank holds depths ranging from 20 to $40 \mathrm{~m}$ at the southwest opening of the TS. The relatively deep Penghu Channel is a narrow passage situated at the southeast of the Taiwan Strait. Except for the Penghu Channel, the Guanyin Depression has the deepest water depth within the Taiwan Strait. Topographic features, monsoon-driven seasonal circulation, and tidal current within the strait, coupled with the temporal discharge rate of fluvial sediments and grain size composition of fluvial material, are the main factors governing the spatial distribution, range of transportation, and budget of sediments in the TS. Below we introduce the general circulation in the ECS (Fig. 1a) and winter circulation in the Taiwan Strait (Fig. 1b). These factors may affect transport and the fate of sediment sourced from Taiwan and mainland China coastal zone.

Winds over the TS are dominated by the East Asia monsoon, from the northeast in winter and from the southwest in summer. The northeast monsoon begins in midSeptember, peaks from October to January, and weakens continuously thereafter. By comparison, the southwest monsoon in June and July is much weaker.

Monsoon effects on the circulation pattern in the TS were reported by Jan et al. (2002). In summer, the main circulation pattern shows that both the Kuroshio Branch (KB in Fig. 1a) current and the South China Sea Warm Current (SCSWC in Fig. 1a) intrude northward. On the eastern side of the TS, the northeastward mean current in summer can be as strong as $90 \mathrm{~cm} \mathrm{~s}^{-1}$ according to Nitani (1972). The southwest monsoon in summer is quite weak, typically $<0.025 \mathrm{~N} \mathrm{~m}^{-2}$, unable to drive a current as strong as $90 \mathrm{~cm} \mathrm{~s}^{-1}$. Thus, the circulation is forced remotely by large scale geostrophic circulation and not local winds (Jan et al. 2002). This northward current is a year-round feature (Guan 1994; Huang et al. 1994; Jan and Chao 2003), connecting the South China Sea Warm Current to the south and the Taiwan Warm Current (TWC in Fig. 1a) to the north of the strait. The large-scale forcing forces waters in the northern South China
Sea to flow northward and enter the East China Sea through the TS.

While in winter, the China Coastal Current (CCC in Figs. $1 \mathrm{a}$ and $\mathrm{b}$ ) is driven by the northeast monsoon, moving sediments from Changjiang (Yangtze; see Fig. 1a) river mouth southward to emerge into the northern TS. The intruding CCC makes a U-turn (Jan et al. 2002, 2004; Lee and Chao 2003) due to the topographic blocking of Yunchang Rise and forms a cyclonic cold eddy over the deep Guanyin Depression (Fig. 1b). During this winter period the windward Kuroshio Branch Current on the eastern side is remotely driven as indicated above, having a reduced northward speed of about $20 \mathrm{~cm} \mathrm{~s}^{-1}$. However, the current in the Penghu Channel (Fig. 1a) flows consistently northward with only rare occasions of southward flow when the winter monsoon is in full blast for a prolonged period (Jan and Chao 2003). As Huang and Yu (2003) suggested, the Penghu Channel is considered as a scour furrow of probably erosion origin, mainly by northward tidal currents. They also indicated the gravel-bedded Penghu Channel serves as a sediment pathway transporting shelf sediment along-shore and northward on the tide-dominated Taiwan Strait shelf.

Due to the strong and persistent northward current in the PHC it is reasonable to set the boundary of the budgeting area to the north of the Penghu Channel. Accordingly, the seven rivers on which we focus may act as major input sources. In this paper, we report mud distributions off the river mouth of the Choshui (River 7 in Fig. 1b), which is the southernmost one of the seven rivers, for pre- and posttyphoon flood periods. This observation provides information about how long riverine mud may stay in the shallow coastal zone off Choshuei.

\subsection{Field Observations}

Three types of data are presented as follows: 1) new field observations for fluvial suspended sediments for the ten primary rivers in Taiwan; 2) new grain size data for surface sediments collected in pre-typhoon and post-typhoon periods at the Choshui River mouth; and 3) data synthesis of grain size and sedimentation rates in the seas surrounding Taiwan.

\subsubsection{Fluvial Sediments during Floods}

Fluvial suspended sediment samples were collected from 10 rivers (Fig. 1b); nine out of ten of which are located in western Taiwan and one is located in northeastern Taiwan. All river samples reported in this study were collected during typhoon periods, which represent their major exports (Kao and Liu 2001; Kao et al. 2005; Syvitski et al. 2005b; Kao and Milliman 2008). Water samples were collected by a custom-designed sampling device, which is composed of a vertically-mounted 1-L bottle attached to a weighted metal frame. During sampling, the sampling device was lowered 
from the bridge and the bottle was gradually filled as the frame sank, thereby affording a depth-integrated sample. We did not use the commonly-used USGS DH-48/76 sampler because it is very difficult to sink into turbulent water under high flow velocity conditions during flood (typically $>4 \mathrm{~m} \mathrm{~s}^{-1}$ ).

During Typhoons, Tim (9 - 11 July 1994), Billis (21 - 23 August 2000) and Mindulle (1 - 3 July 2004), we conducted intensive sediment samplings ( 3 - 4 hours interval) during flood inundation and recession for the Danshuei (River 1), Lanyang (River 10), and Choshui (River 7) rivers, respectively (see Fig. 1b for river locations) (Time series data of intensive flood sampling are shown in Appendix 1). In addition to the three flood event monitoring cases, we collected samples from nine western rivers during the flood recession period of typhoons Doug (6 - 8 August 1994) and Nari (6 - 19 September 2001). All turbid flood water samples were taken into the lab for grain size and concentration analyses. Wet sediment samples were filtered by using GF/F filters, which were then dried in oven at $60^{\circ} \mathrm{C}$ and weighed for total suspended matter (TSM, in $\mathrm{g} \mathrm{L}^{-1}$ ) calculation. Aliquot sediments were passed through $62 \mu \mathrm{m}$ stainless steel sieve for mud separation.

\subsubsection{Near-Shore Sediments off the Choshui River}

Marine sediments were taken from the shallow coastal zones (from shoreline to $35 \mathrm{~m}$ ) off the Choshui River mouth. Two cruises were conducted (one in July 1996 and the other in March 1997). A total of 196 samples (20 offshore transects and $\sim 10$ samples for each transect, see Fig. 4) were collected in each cruise by using dredges on a fishing boat. Sediment samples were taken to the lab for grain size separation as described above. Sampling locations and analytical results are listed in Appendix 2. Between the two cruises, Super-Typhoon Herb (31 July - 1 August 1996) invaded Taiwan, resulting in a $130 \mathrm{Mt}$ suspended sediment output from the Choshui River (details can be seen in Milliman and Kao 2005). This case allowed us to examine the grain size distribution pattern of sediments in the coastal zone before and after a significant sediment discharge event with an interval of seven months.

\subsection{Grain Size and Mass Accumulation Data Compilation}

For grain size data compilation, one database and 9 previous studies (area coverage and study code are shown in Fig. 2a) with available data (collectively 790 data points) are applied. Published data cover most of the areas surrounding Taiwan, including the Kaoping Canyon off southwest Taiwan and the southern Okinawa Trough off north- (a)

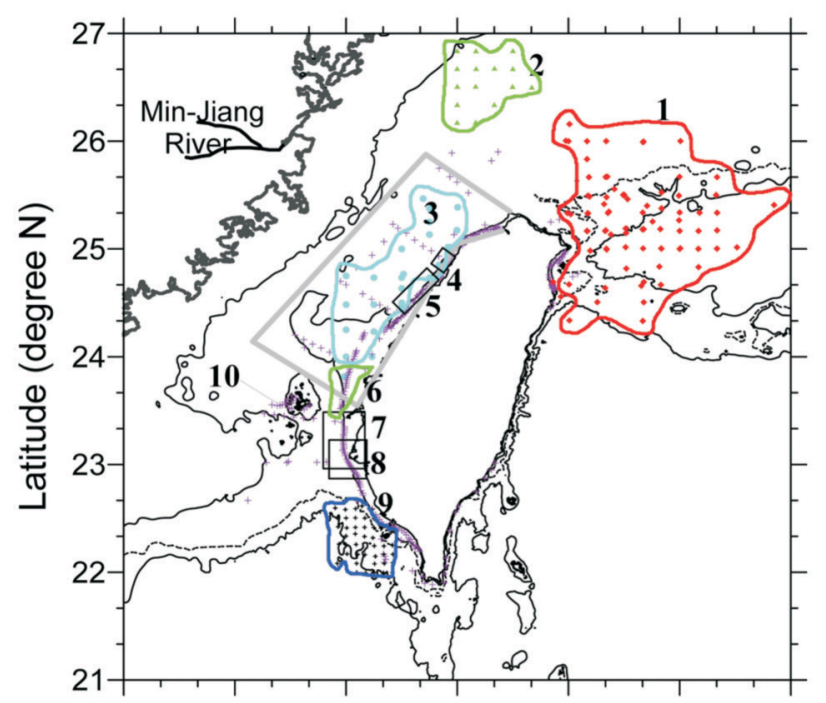

(b)

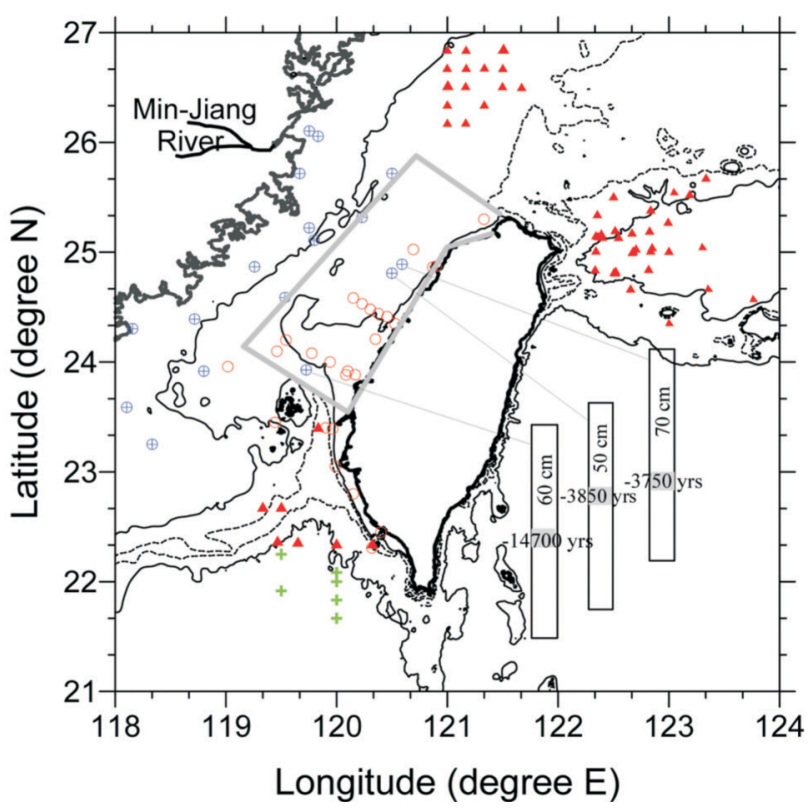

Fig. 2. (a) Spatial coverage of studies (labeled with area code numbers) with grain size data are reported: 1) 74 samples from National Center for Ocean Research, Taiwan; 2) 15 samples from Lin et al. (2000); 3) 25 samples from Chen et al. (1988); 4) 52 samples from Chen et al. (1997b); 5) 38 samples from Chen et al. (1997c); 6) 196 samples in this study; 7) 150 samples from Fang and Hong (1999) and Hong et al. (2004); 8) 194 samples from Liu et al. (2000); 9) 46 samples from Chen (1997d) and Liu et al. (2002); and the 314 purple crosses are data points from Chen and Lin (1997a). (b) Location map for reported mass accumulation rates. Red triangles are for accumulation rates derived by ${ }^{137} \mathrm{Cs}$ and ${ }^{210} \mathrm{~Pb}$. Blue circles with crosses are for ${ }^{14} \mathrm{C}$-derived accumulation rates. Red circles stand for ${ }^{10} \mathrm{Be}$-derived accumulation rates. Green crosses are for mass accumulation rates derived from magnetic inclination. Gray box represents the budgeting area in this study. Columns are core examples of ${ }^{14} \mathrm{C}$ dating for mass accumulation calculations. 
eastern Taiwan (Figs. 1b, 2a). Mean conditions of the preand post-typhoon data we collected at the river mouth of the Choshui were combined with all previously reported data for mapping the spatial distribution of mud around Taiwan.

Since most of the areas in the Taiwan Strait are covered by sand, no studies had been done for mass accumulation rates (MAR) using ${ }^{210} \mathrm{~Pb}$ and ${ }^{137} \mathrm{Cs}$ in the strait. Fortunately, the sedimentation rates had been previously measured by ${ }^{14} \mathrm{C}$ dating (Chen and Covey 1983; Xu et al. 1989, 1990) in shell intervals in the middle of cores at 19 sites (see examples in Fig. 2b) and by using ${ }^{10} \mathrm{Be}$ at 26 sites (Lee at al. 1993). Lee et al. (1993) indicated that ${ }^{10} \mathrm{Be}$ method is suitable for areas undergoing rapid deposition. Interestingly, the MARs in the Taiwan Strait derived by ${ }^{10} \mathrm{Be}$ method compared well with those determined by ${ }^{14} \mathrm{C}$ dating and the MARs in the modern basin are even comparable to the deposition rates in the paleo-basin of western Taiwan on a million-year basis (Lee et al. 1993).

Those ${ }^{14} \mathrm{C}$ dating data are particularly valuable since they give a longer-term average different to the short-term sedimentation rates provided by ${ }^{210} \mathrm{~Pb}$ or ${ }^{137} \mathrm{Cs}$. This helps us to better constrain the sedimentation budget since the Taiwan Strait submerged during the Holocene. In Fig. 2b, we provide three example cores near the coastal region of Taiwan. In those cores, thin sediment layers on the top of dated shell layers strongly indicate low sediment burial flux on a millennium scale. We use a wet bulk density of $2 \mathrm{~g} \mathrm{~cm}^{-3}$ to transform those ${ }^{14} \mathrm{C}$-derived linear sedimentation rates to the mass accumulation rate. This value represents the upper limit of wet bulk density in seas surround Taiwan. By using this number, the ${ }^{14} \mathrm{C}$-derived mass accumulation rate becomes the upper limit.

Accordingly, all 45 data points were used in contour mapping for MAR distribution. An ideal spatial distribution map is not possible as it is impossible to have sufficient data points; however, given the time scale of several thousand years, the available reported data points give good coverage within the Taiwan Strait. For nearby areas outside of the strait (see Fig. 2b), we use previously published sediment accumulation rates derived from ${ }^{210} \mathrm{~Pb}$ - and ${ }^{137} \mathrm{Cs}$ (Chung and Chang 1995; Huh and Su 1999; Lin et al. 2002; Lee et al. 2004) and magnetic inclination (Chen and Leu 1984); the results of which must be treated with caution due to differences in methodology. Thus, the basic assumption used to calculate the burial term is that the sedimentation pattern is steady over the last 5000 years since the sea level reached its present level (see Liu et al. 2007 and references therein).

\subsection{Sediment Flux Calculation for Taiwanese Rivers}

With consideration given to the high degree of fluctuation in Taiwan river systems, a sophisticated sediment load calculation has been published by Kao et al. (2005), in which a historical rating relationship for the primary rivers and a method for uncertainty calculation were reported. They developed stratified time-frame rating curves for each river, reflecting yearly and seasonal changes in sediment yields and water discharge. Using a FORTRAN program that incorporates limited range extrapolation in water discharge, representative data points, and meaningful regressions, Kao et al. (2005) determined that the optimal timeframe for meaningful rating curves was to separate yearly data into low-flow (November - May) and high-flow (July October) months. Time-stratified rating curves were then applied to daily, and where needed, hourly discharges to calculate annual suspended sediment loads. A bias-correction factor was also introduced to reduce the estimation residuals; when combined with hourly discharge data, they successfully predicted sediment fluxes and concentrations in response to episodic events, particularly during typhoons.

Here, we followed Kao et al. (2005) to estimate sediment discharge for western rivers in Taiwan. Total sediment discharge from 21 primary rivers in Taiwan was reported to be $380 \mathrm{Mt} \mathrm{y}^{-1}$ by Dadson et al. (2003), $240 \mathrm{Mt} \mathrm{y}^{-1}$ by the Water Resources Agency (WRA) (Hydrologic Yearbooks by WRA: http://www.wra.gov.tw/) and $184 \mathrm{Mt} \mathrm{y}^{-1}$ by Kao and Milliman (2008).

Sediment fluxes vary widely among rivers regardless of the calculation methods. Based on the method by Kao et al. (2005) and data archive in WRA, the annual means of sediment flux for the ten rivers we focused on range from 0.5 to 37.6 Mt y ${ }^{-1}$ with a summarized total of $92.5 \mathrm{Mt} \mathrm{y}^{-1}$ (Table 1). For individual rivers, the maximum and minimum annual sediment loads may vary over 20 -fold. Here we assume the record is long enough to represent the long-term mean. The estimation uncertainty for each flux value is represented by lower and upper limits (Table 1), which are derived respectively from pooled positive and negative residuals in calculation (See Kao et al. 2005).

For the seven rivers flowing into the Taiwan Strait (Rivers 1 through 7), the total sediment load is $52.5 \mathrm{Mt} \mathrm{y}^{-1}$, ranging between 40.8 and $58.8 \mathrm{Mty}^{-1}$ (Table 1 ; other smaller rivers that drain the low western plain sediment load were ignored due to their small sediment yields and relatively small area). Since all these load values are derived from 30 50 year records (see Kao et al. 2005), both anthropogenic effect and natural variability are included. Human activities, such as agriculture and road construction, initiate soil exposure increasing the amount of soil run off during torrential rains caused by typhoons. This tightly correlated timing, unfortunately, makes it hard to differentiate the effects of human activity and natural forcing on sediment output. Of the rivers in this study, only the Lanyang River (River 10) has long enough hydrologic data and records of road construction to allow for an assessment of anthropogenic effects (Kao and Liu 2002; Syvitski and Milliman 2007). For example, the Lanyang River had a 4-fold increase in sediment load following two road construction events and these 
anomalous events lasted for only 4 years (Kao and Lin 2002). However, for the western rivers, no significant human effects can be identified. Earthquake and/or upstream road construction coupled with typhoon-induced torrential rainfall trigger landslides and bank erosion, which are the most important sources for riverine sediments. The relative importance of each of these driving forces is still being evaluated (Hovius et al. 2000; Kao and Liu 2002; Dadson et al. 2003, 2004; Kao et al. 2005).

Nevertheless, river channel incision data from island wide Taiwan are consistent with modern high sediment yield values (Dadson et al. 2003), suggesting persistently high sediment erosion over at least several tens of thousands of years. Based on Kao et al. (2005) we apply mean values of sediment loads derived from WRA's entire historical records for all ten rivers to calculate a sediment budget in surrounding seas. Also we assume all the calculated sediment fluxes were entirely delivered into the sea ignoring deposition on river mouths and the Tsengwen River delta. This assumption is very likely true since major sediment fluxes are contributed during flood periods with great energy.

\subsection{Estimation of Sediment Burial}

Estimation of sediment burial is limited to the eastern part of the Taiwan Strait $\left(23300 \mathrm{~km}^{2}\right.$; box shown in gray solid line in Fig. 2b) since the reported grain size data is mainly distributed in the eastern part of the strait.

Total mass accumulation was separated into two fractions, namely, mud burial and sand burial. To obtain the burial rates, we firstly grid bulk MAR (in $\mathrm{g} \mathrm{cm}^{-2} \mathrm{y}^{-1}$ ) data at equal pixel space $\left(1 / 10^{\circ}\right)$ by using the Kriging method in Surfer (PC software). The grid process generated the contour map and gave us interpolations for unmeasured pixels. Secondly, we grid mud (\%) data at the same space interval to make the grid pixels match those in the MAR calculation. By overlapping the two contour maps, mud burial rate in each pixel can be obtained by multiplying the MAR value by the mud fraction in respective pixels.

Here we present uncertainties in burial estimation. Kriging procedure consists of three steps. First, all possible pairs of data points are examined, the pairs are grouped by distance classes, and the semivariance (half the variance of the difference in values) is graphed vs. the distance class. This is the 'sample semivariogram' and shows the degree of spatial autocorrelation as a function of distance between points. Second, a curve ('model semivariogram') is fit to these points by least-squares regression. Lastly, this model is used to determine the weights for the nearby supporting data points to compute the estimate for the desired unmeasured point. A common form of the semivariogram model is defined by the nugget variance (the variance at zero distance), this sill (the variance to which the semivariogram asymptotically rises), and the range (the distance at which the sill or some predetermined fraction of the sill is reached). Details can be seen in Phillips and Marks (1996), in which uncertainty analysis for Kriging was discussed. By following their report, the interpolation-induced spatially varying uncertainty was calculated by removing one single data point on the map each time to obtain a contour map. By iterating this step, we obtain as many contour maps as observation data points. Finally, by overlapping all contour maps, we have a mean contour map, in which mean and variance in each pixel can be derived.

Both sedimentation rate and mud fraction contours were derived based upon the procedure. Multiplying the two mean values in each respective pixel, we derived a mean value of mud burial for each pixel. Summarizing together mean values from all pixels in the budget area, we gained the number of total mud burial. Meanwhile, means and variances in all pixels over two maps were used to derive bulk uncertainty based on:

$U_{A}=\frac{\sum_{i, j \subset A} \sqrt{\begin{array}{l}\operatorname{Var}\left(S R_{i, j}\right) \times \operatorname{Var}\left(M u d_{i, j}\right)+E^{2}\left(S R_{i, j}\right) \\ \times \operatorname{Var}\left(\operatorname{Mud}_{i, j}\right)+E^{2}\left(M u d_{i, j}\right) \times \operatorname{Var}\left(S R_{i, j}\right)\end{array}}}{N_{A}}$

Here, $U_{A}=$ average of standard deviation in each pixel inside area $A$,

$N_{A}=$ total pixel number in area $A$,

$\operatorname{Var}\left(S R_{i, j}\right)=$ the variance of $S R$ in $(i, j)$,

$E\left(S R_{i, j}\right)=$ the mean of $S R$ in $(i, j)$,

$\operatorname{Var}\left(M u d_{i, j}\right)=$ the variance of $S R$ in $(i, j)$,

$E\left(\operatorname{Mud}_{i, j}\right)=$ the mean of $M u d$ in $(i, j)$.

\section{RESULTS AND DISCUSSION}

\subsection{Concentration and Grain Size Composition of Flood Sediments}

The three floods were monitored over a wide range of water discharge (Fig. 3). During those periods, sediment concentrations varied over three orders of magnitude from $<0.1 \mathrm{~g} \mathrm{~L}^{-1}$ at low flows to $\sim 200 \mathrm{~g} \mathrm{~L}^{-1}$ at high flows. The hydrological response with respect to rainfall was very fast (Fig. 3). The water discharge rate increased from several cms to 2 - 3 orders of magnitude within several hours. The flow rate peaked at 2 - 3 hours after the precipitation peak. Suspended sediment concentration varied concomitantly with the water discharge rate.

The maximum sediment concentration was $\sim 6,25$, and $200 \mathrm{~g} \mathrm{~L}^{-1}$ (Fig. 3), respectively, for the Danshuei, Lanyang and Choshui rivers (see Fig. 1b). The relatively lower maximum concentration observed in the Danshuei is consistent with the long-term observations reported by the Water Resources Agency in Taiwan (Fig. 1 in Milliman and Kao 2005). Such lower concentrations are attributed to limited 

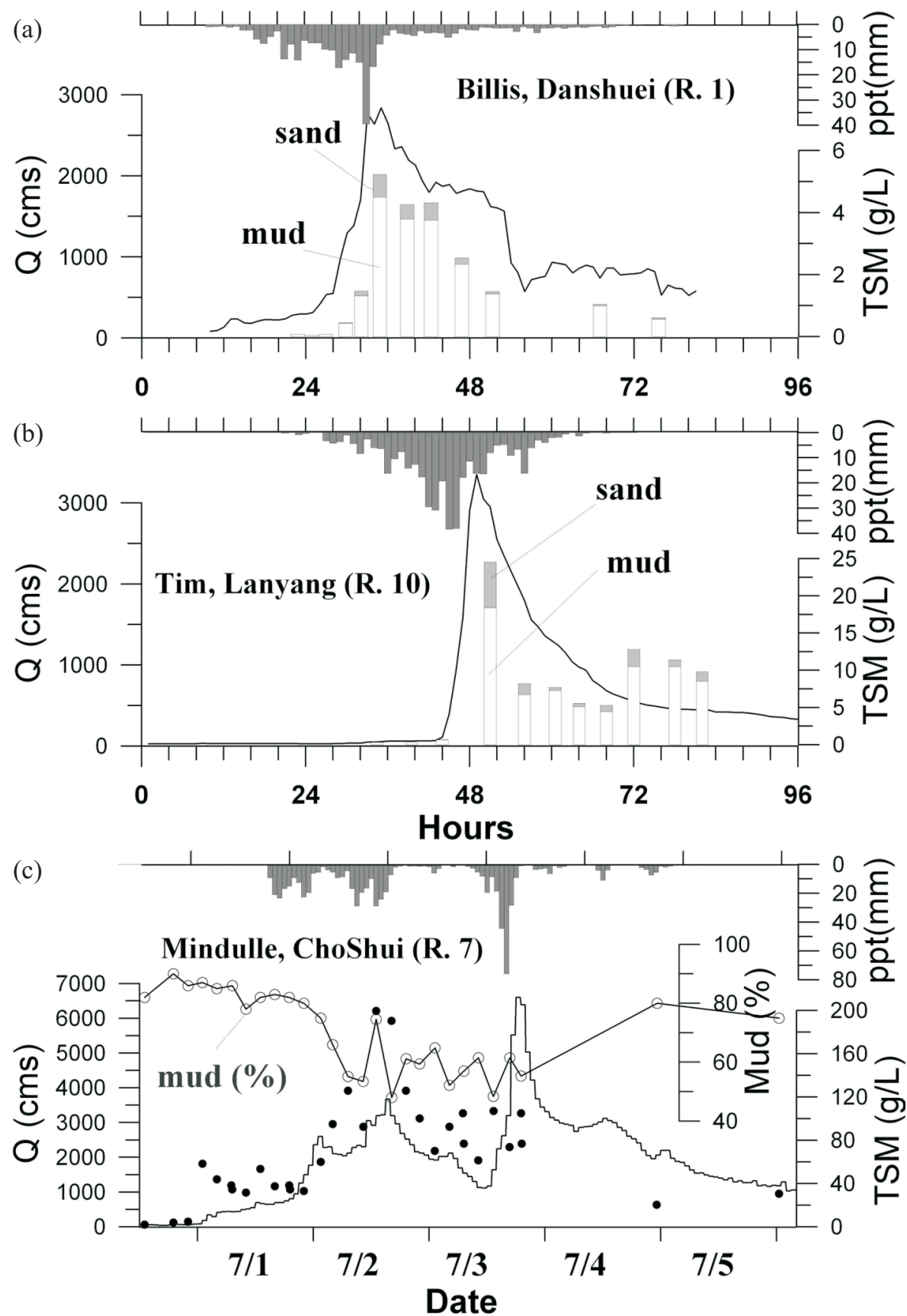

Fig. 3. Typhoon monitoring for: (a) the Danshuei River during Typhoon Billis; (b) the Lanyang-Hsi River during Typhoon Tim; and (c) the Choshui River during Typhoon Mindulle. Rain precipitation (ppt, in mm, represented by inverse gray columns), flow rate (Q, in $\mathrm{cm} \mathrm{s}^{-1}$, shown in solid curves) and total suspended matter concentration [TSM in $\mathrm{g} \mathrm{L}^{-1}$ shown with stacked columns in (a) and (b) and dots in (c)] are shown in time series. Line with open circles in (c) represents percentage abundance of mud.

sediment supplies since the watershed is well protected and two water reservoirs located at the middle reaches may block a significant portion of suspended sediments sourced from upstream. In contrast, the moderately high concentrations observed in the Lanyang are caused by intensive agricultural activities upstream and on the middle-reaches floodplain (Kao and Liu 2001, 2002). The extremely high concentration found at the Choshui River was attributable to its friable basement rocks. In addition, the baseline of se- dimentation concentration during low flow conditions has been elevated and systematically higher sedimentation concentrations over water discharge rates were observed in those years after the 1999 Chi-Chi earthquake (Dadson et al. 2004) revealing a watershed scale disturbance; though the effects of earthquake disturbance may not last for more than 5 years.

In the Choshui case, mud fractions decreased with the increase of flow rates (Fig. 3c). During the peak flow, mud 
fraction dropped down to $\sim 50 \%$, which is the lowest fraction found in all flood observations. Higher concentrations and fractions of sand during high flow reflect the elevated sediment carrying capacity due to the increase of flow velocity and stream power. The flux-weighted mean fractions of mud over those event periods are $92 \%, 87 \%$, and $70 \%$, respectively, for the Danshuei, Lanyang, and Choshui rivers (Table 2 and Appendix 1). And, the sediment transport caused by the single event of Mindulle is $51 \mathrm{Mt}$, of which mud accounted for $35 \mathrm{Mt}$.

Suspended sediment concentrations observed at the other nine western rivers during invasions of Typhoon Doug and Nari are listed in Table 2 separately. The sediment concentrations observed during the two typhoons ranged from 0.5 to $12.9 \mathrm{~g} \mathrm{~L}^{-1}$. Regardless of the large spatial variability in concentrations, observed mud fractions were always higher than $79 \%$ and the highest record was $98 \%$. Apparently, mud dominates the fluvial discharges for all those western rivers. In the following mud budget calculation, we assume $70 \%$ to be the lower limit for fractional contribution of mud to fluvial sediment inputs.

\subsection{Mud Patches off the Choshui River Mouth before and after Typhoon Herb}

Between the two cruises, Super-Typhoon Herb contributed $130 \mathrm{Mt}$ sediments (Milliman and Kao 2005). Assuming half is mud $\left(\sim 5 \times 10^{7} \mathrm{~m}^{3}\right)$, a 10 -cm thick mud deposition should be found covering an area of $500 \mathrm{~km}^{2}$. However, results from the 196 samples collected off the Choshui River coast in the post-typhoon cruise showed that near-shore $(<-35 \mathrm{~m})$ surface sediments are dominated by sand with most areas having mud fractions $<20 \%$ (Fig. 4), not to mention the $10-\mathrm{cm}$ mud deposits. Meanwhile, no significant differences appear in contour maps between pre- and post-typhoon cruises. This result is consistent with previous reports that sand fraction dominated surface sediments at the coastal zone off the Tsengwen River (River 8 in Fig. 1b) (Fang and Hong 1999; Liu et al. 2000).

Figure 4 reveals mud patches within limited areas at the north off the river mouth in both cruises reflecting a northward transport. For most areas mud fraction in surface sediments is $<20 \%$, which is much lower than mud fractions observed in suspended sediments during the typhoon periods. Deficit in mud percentage and sparely patched mud indicate that most of the fluvial sediment sourced from the Choshui had been dispersed out of the near-shore region.

The second cruise was conducted 6 months after Typhoon Herb. In between the two cruises, the northeast monsoon wind prevailed. Very possibly, the fluvial muds were deposited temporarily after the typhoon events and re-suspended due to waves driven by the prevailing monsoon wind and transported out of the coastal area. Alternatively, the fluvial mud might have never been deposited. Instead, they might have been transported far away during the storm period since a high fluvial discharge rate always accompanies turbulent marine conditions caused by the strong wind brought by typhoons.

\subsection{Mud Distribution and Sediment Mass Imbalance in the Taiwan Strait}

Putting together new observations and all previously reported data, a contour map for mud distribution surrounding Taiwan shows that areas with mud fraction $>75 \%$ mainly locate in three regions: 1) central north strait connecting to 26 -

Table 2. Total suspended matter $\left(\mathrm{g} \mathrm{L}^{-1}\right)$ and the percentage abundance of mud observed during Typhoon events at ten rivers in Taiwan.

\begin{tabular}{lcccccccccc}
\hline Typhoon year & \multicolumn{2}{c}{ Doug (1994) } & \multicolumn{2}{c}{ Nari (2001) } & \multicolumn{2}{c}{ Billis (2000) } & \multicolumn{2}{c}{ Mindulle (2004) } & \multicolumn{2}{c}{ Tim (1994) } \\
\hline Code, River & $\begin{array}{c}\text { TSM } \\
\left(\mathrm{g} \mathrm{L}^{-1}\right)\end{array}$ & $\begin{array}{c}\text { Mud } \\
(\%)\end{array}$ & $\begin{array}{c}\text { TSM } \\
\left(\mathrm{g} \mathrm{L}^{-1}\right)\end{array}$ & $\begin{array}{c}\text { Mud } \\
(\%)\end{array}$ & $\begin{array}{c}\text { TSM } \\
\left(\mathrm{g} \mathrm{L}^{-1}\right)\end{array}$ & $\begin{array}{c}\text { Mud } \\
(\%)\end{array}$ & $\begin{array}{c}\text { TSM } \\
\left(\mathrm{g} \mathrm{L}^{-1}\right)\end{array}$ & $\begin{array}{c}\text { Mud } \\
(\%)\end{array}$ & $\begin{array}{c}\text { TSM } \\
\left(\mathrm{g} \mathrm{L}^{-1}\right)\end{array}$ & $\begin{array}{c}\text { Mud } \\
(\%)\end{array}$ \\
\hline 1. Danshuei & 3.5 & 95 & 2.0 & 95 & $0.1-5.2$ & 92 & & & \\
2. Tochian & 1.5 & 97 & 1.1 & 98 & & & & & \\
3. Holung & 0.5 & 97 & 0.5 & 98 & & & & & \\
4. Daan & 4.3 & 92 & 5.1 & $\mathbf{8 7}$ & & & & & \\
5. Dajia & 4.6 & 85 & 3.1 & 79 & & & & & \\
6. Wu & 3.9 & 92 & 5.8 & 94 & & & & & \\
7. Choshui & 6.5 & 81 & 9.5 & 98 & & & $0.2-199.6$ & 70 & \\
8. Tsengwen & 12.9 & 81 & 3.5 & 91 & & & & & \\
9. Kaoping & 3.6 & 92 & 4.0 & 92 & & & & & & \\
10. Lanyang & & & & & & & & & \\
\hline
\end{tabular}




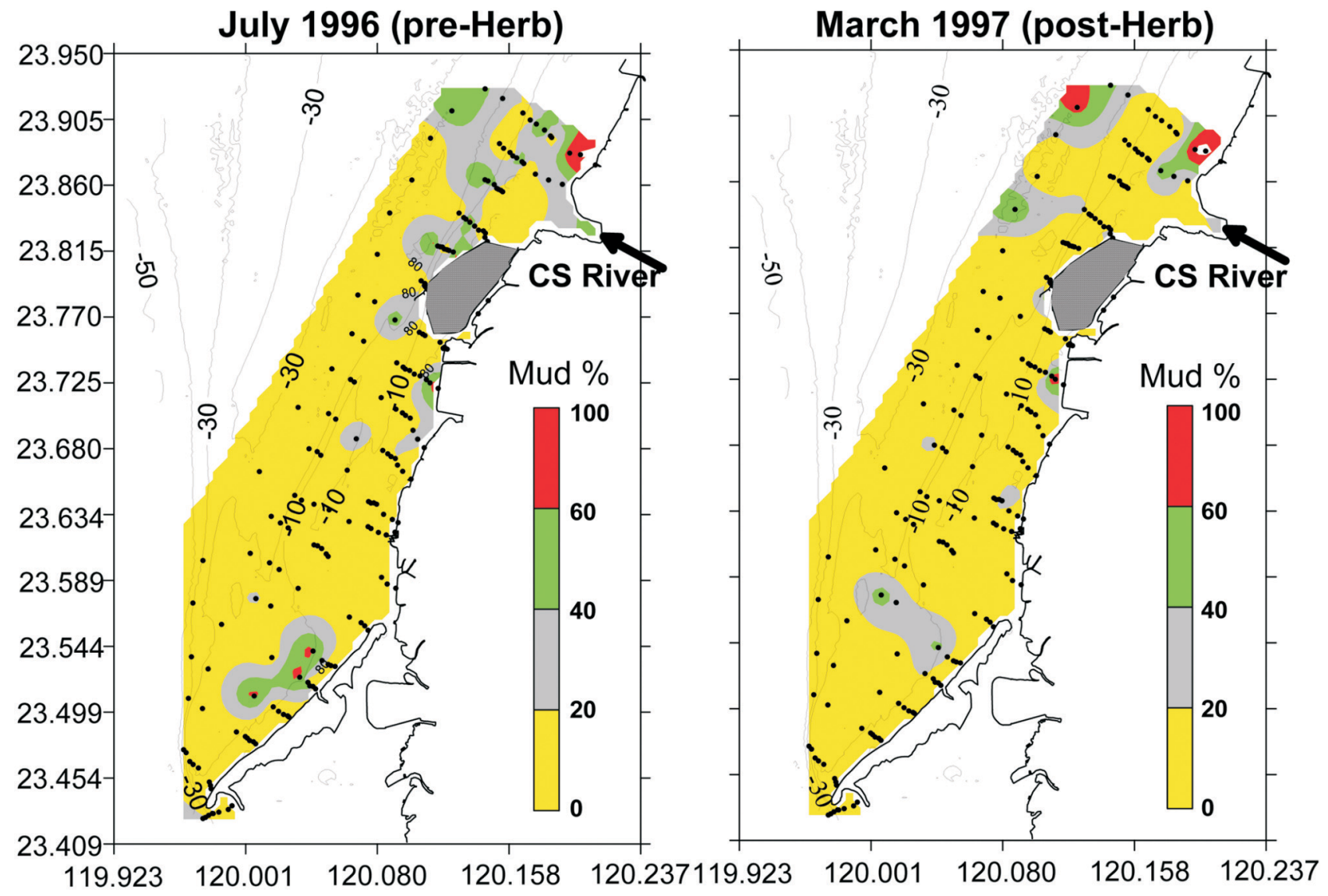

Fig. 4. The contour map of mud off the coast of the Choshui (CS) River in July 1996 (before Typhoon Herb) and in March 1997 (after Typhoon Herb). Isopleths are shown in curves. Solid dots represent sampling locations.

$27^{\circ} \mathrm{N}$ near the coast of mainland China; 2) the southern Okinawa Trough (SOT); and 3) the southwestern continental slope off Taiwan (Fig. 5a). The latter two will be discussed in the next section.

Within the Taiwan Strait, the presence of mud patches in the central area (Fig. 5a) agrees with the first report of grain size distribution in surface sediments in the TS by Boggs et al. (1979). The mud distribution pattern is approximately coincident with the bottom topography of the strait where muddy sediments ( $>75 \%$ of mud) mostly deposit in the deep Guanyin Depression (Fig. 1b), and coarser sediments $(<25 \%$ of mud) reside over the shallow YCR, deep PHC, and in the eastern part of the strait. The distribution pattern is attributable to the variation of tidal dissipation (see tidal ellipse in Fig. 5a) and seasonal circulations over the complicated topography. The major tidal current ellipses (M2 tide) derived from model results of Jan et al. (2004) showed that tidal currents are weak in the middle sections with deep water depth (the Guanyin Depression) and strong over shallow shoals (the Taiwan Banks) and coastal regions adjacent to northwest and southwest of Taiwan island. The spatial variations of muddy and sandy sediments essentially match the relatively weak and strong tidally induced bottom friction regions, respectively. However, sources of the mud patched in the Guanyin Depression are not known.

For the area we focused on in the strait, the areaweighted mass accumulation rate is $76 \mathrm{mg} \mathrm{cm}^{-2} \mathrm{y}^{-1}$ with most areas $<100 \mathrm{mg} \mathrm{cm}^{-2} \mathrm{y}^{-1}$. Rates higher than $300 \mathrm{mg} \mathrm{cm}^{-2} \mathrm{y}^{-1}$ are restricted at the eastern strait (Fig. 5b). A seaward decrease in MAR with increasing water depth is revealed. The increasing distance away from the sediment sources from the western rivers explains such a decreasing trend. According to our estimates, we obtained an annual total sediment burial output of $18 \mathrm{Mt} \mathrm{y}^{-1}$, which comprises $12 \pm 10 \mathrm{Mt}$ of sand and $6 \pm 5 \mathrm{Mt}$ of mud in the box area.

A recent chirp sonar survey (J. P. Liu, pers. Comm.) in the Taiwan Strait reveals a similar mud distribution pattern as shown in this study. The maximum thickness of the mud patch in central TS is around $20 \mathrm{~m}$. Taking an area of $150 \times$ $20 \mathrm{~km}$ and average thickness of $10 \mathrm{~m}$ (suggested by J. P. Liu) for the mud patch in our boxed region then the total mud burial in the study area should be $3 \times 10^{5} \mathrm{Mt}$. By assuming a mud deposition $(100 \%$ mud) that started 5000 years ago when the sea level reached its present level, we obtain the

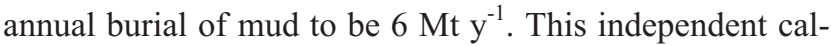
culation derived from chirp data confirms the low burial 
(a)

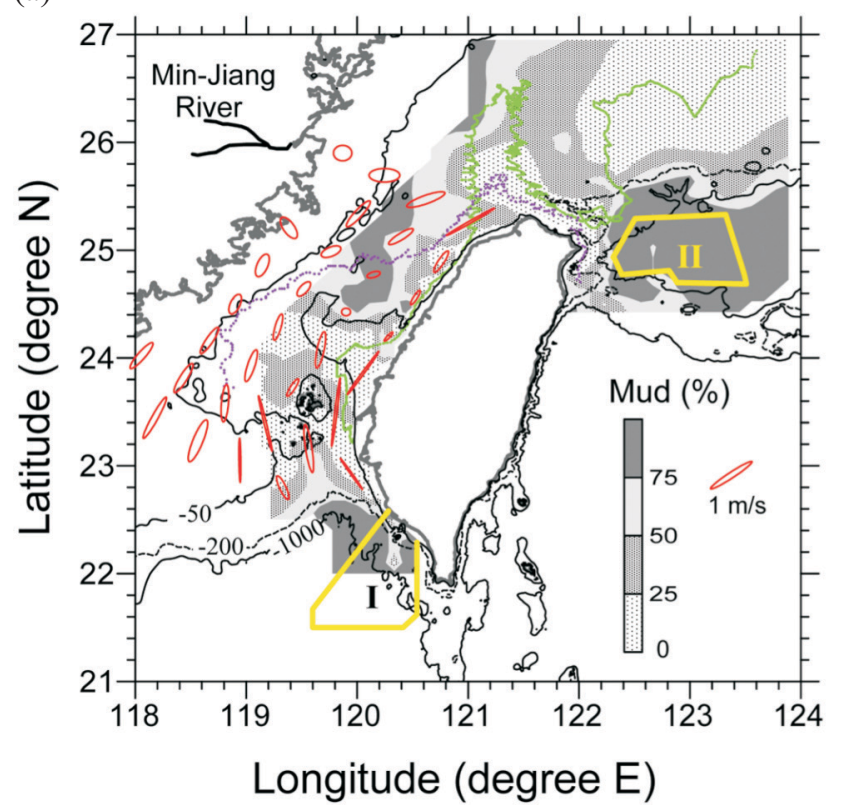

(b)

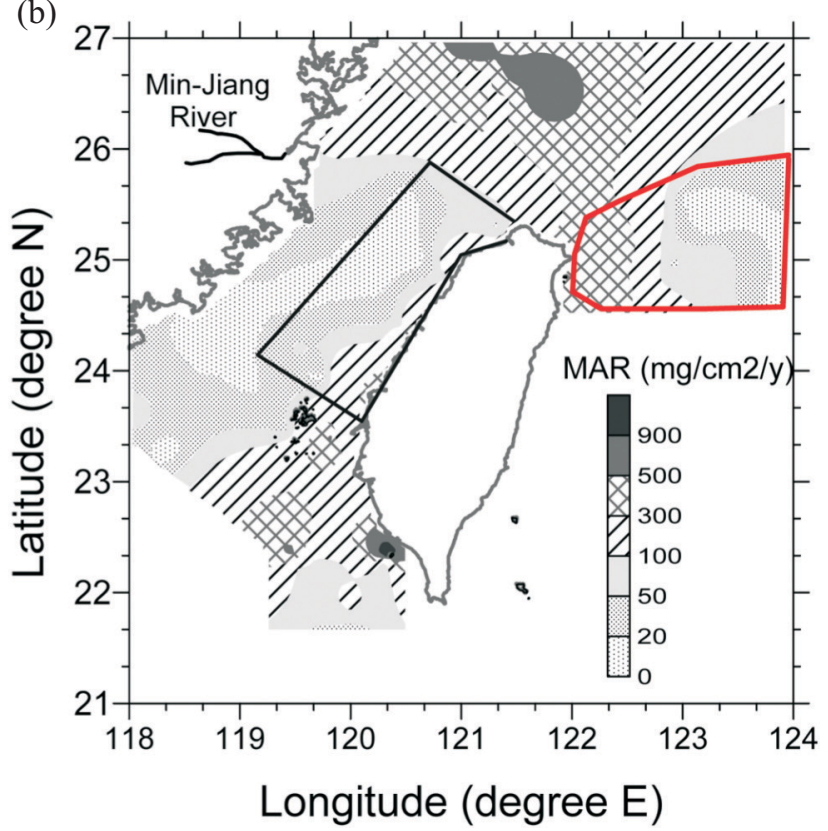

Fig. 5. (a) Contour map of the mud fraction. Water depths of 50, 200, and $1000 \mathrm{~m}$ are in curves. Tidal ellipses (in red) and the drifter trajectories observed in May (in purple) and in Nov. (in green) are overlaid with mud distribution patterns for comparison. Yellow lined regions, I and II, are reported by Kao et al. (2006) and Huh et al. (2006), respectively, for sediment burial outputs (see text and summary below). The tidally induced bottom friction can be seen in the Fig. 3c in Jan et al. (2004). (b) Contour map of mass accumulation rate. Budgeting area is marked by a black bold line.

flux of mud in the Taiwan Strait.

The input term, which was obtained by summarizing the mean annual discharge of suspended sediment from western rivers, is method-dependent. Based on Kao et al (2005), the cumulative sediment fluxes for the seven rivers during 1970 - 2002 is $1160 \mathrm{Mt}$ with an average of $53 \mathrm{Mt} \mathrm{y}^{-1}$ (Table 1), which is slightly lower than that reported in the Hydrological Yearbook by the Water Resources Agency in Taiwan (71 Mt y ${ }^{-1}$; method had been detailed in Kao et al. 2005). Here, we took $60 \mathrm{Mt} \mathrm{y}^{-1}$ as the sediment input for Rivers 1 through 7.

On the other hand, the source term may change with climate conditions. As indicated by Yuan et al. (2004) summer monsoon and precipitation peaked around 8000 years ago and remained lower with less fluctuation in the past 5000 years at latitude $25^{\circ} \mathrm{N}$ in southern China. The paleomonsoon effect on water runoff and sediment load is hard to evaluate. Here we assume the input term is representative of the past 5000 years as supported by river incision data (Dadson et al. 2003). Based on our typhoon monitoring (30\% sand and $70 \%$ mud) and $60 \mathrm{Mt} \mathrm{y}^{-1}$ sediment input, the sand and mud inputs were estimated to be $18 \pm 5$ and $42 \pm$ $11 \mathrm{Mt} \mathrm{y}^{-1}$, respectively. Notably, in most flood cases, the mud fraction is much higher than $70 \%$; therefore, our calculated mud input may serve as the lower limit and sand input may serve as the upper limit in budget calculation.

Compared to the fluvial sand input $\left(18 \pm 5 \mathrm{Mt} \mathrm{y}^{-1}\right)$, sand burial output $\left(12 \pm 10 \mathrm{Mt} \mathrm{y}^{-1}\right)$ in the strait is lower yet within the acceptable range. However, the mud burial $\left(6 \pm 5 \mathrm{Mt} \mathrm{y}^{-1}\right)$ is significantly lower compared to the fluvial input of $42 \pm$ $11 \mathrm{Mt} \mathrm{y}^{-1}$. The significant shortfall in the mud burial term suggests that abundant fluvial mud had gone somewhere out of the strait.

On the other hand, mud shortage is likely higher due to two extra inputs since: 1) mud patched in central Taiwan Strait is suggested to be sourced from the Changjiang and Minjang rivers (Chen et al. 1988), and 2) very possibly a portion of mud sourced from non-counted rivers south of the Choshui are transported into the box area through the PHC by Kuroshio Branch.

As indicated earlier, the mud belt along the mainland China coast extends from the Changjiang River mouth to the northern Taiwan Strait (Zhao and Yan 1994; Hu et al. 1998). The Changjiang sediments were transported southward by the China Coast Current (CCC, Figs. 1a and b) during the northeast monsoon (Milliman et al. 1985; Liu et al. 2003). The intruding CCC in winter makes a U-turn (Jan et al. 2002, 2004; Lee and Chao 2003) due to the topographic blocking of YCR and thus forms a cyclonic cold eddy over the deep Guanyin Depression as shown in Fig. 1b. The Changjiang sediments carried by the CCC might temporally deposit in the central TS (Boggs et al. 1979; Chen et al. 1988) and/or move eastward across the shelf at the northern TS (Kao et al. 2003; Liu et al. 2003). The wintertime circulation pattern likely suggests that patched sediments in the Guanyin Depression are sourced from the coastal zone of China. However, its contribution is not clearly known.

On the other hand, the northward subtidal currents along 
the west coast of Taiwan are at their peak in summer (Jan and Chao 2003), during which abundant sediment are delivered. The strong and persistent northward KB through the Penghu Channel (Fig. 1a) not only eliminates the possibility of the southward movement of fine-grained suspended sediments (Huang and Yu 2003; Jan and Chao 2003) but also shows great potential to drive fine sediments discharged by other rivers, such as Tsengwen and its nearby small rivers (not shown), northward to the boxed region (see Fig. 1b). The total sediment delivery by Tsengwen and its nearby rivers (e.g., Erjen River, can be seen in Kao et al. 2005) is around $30 \mathrm{Mt} \mathrm{y}^{-1}$ (Kao et al. 2005). To what extent this amount of sediment enters the TS is also unknown. Nevertheless, the two extra inputs from the north and south opening may promote the imbalance of mud in the TS.

\subsection{The Fate of Missing Mud and Future Studies}

Overall, the missing mud is likely carried by the northward current in the TS. An important feature in the mud contour plot is the mud tongue at the north of the TS (Fig. 5a). The mud tongue extends from the Chinese coastal mud belt to the SOT area, consistent with the spatial distribution of total organic carbon content and organic carbon isotopic composition in surface sediments reported by Kao et al. (2003), and with the drifter trajectories of surface currents (see below). The question arises as to whether it is possible that Taiwan mud merges with mud from China's coast and is transported eastward to the Okinawa Trough.

A drifter study conducted by Tseng and Shen (2003) provided insights into the potential pathways of sediment transport. In their November 1997 observation, water parcel trajectory (Fig. 5a, green curve) left the strait moving northward to China's coastal mud belt around $26^{\circ}$ (Fig. 5a), and then turned southeastward moving toward the SOT (Fig. 1b). In their May observation (purple curve in Fig. 5a), the drifter went from the central TS to the northeastern TS and then turned clockwise, directly passing through the Mian-Hwa Canyon (see Fig. 1b) to the SOT. This drifter observation is consistent with three-dimensional numerical model simulations in the ECS (Lee and Chao 2003) and in the Taiwan Strait (Jan et al. 2004). Though drifter trajectory represents the flow path of surface current, in the shallow Taiwan Strait, the surface circulation pattern is quite consistent with that of the bottom layer (Jan et al. 2004). Amazingly, the November drifter trajectory matches the spatial pattern of the mud tongue quite well at the northern Taiwan Strait (Fig. 5a) revealing the potential transport of Taiwan mud into the SOT.

The across-shelf paths of particle transport from the East China Sea to the Okinawa Trough are not only driven by winter circulation but also enhanced by the year-round cyclonic eddy off northeastern Taiwan (Liu et al. 2003). As the main stream of the Kuroshio encounters the shelf break of the ECS, a cyclonic eddy forms off northeastern Taiwan
(Fig. 1a), while the Kuroshio turns northeastward. The cyclonic eddy may suck the sediments offshore to the southern Okinawa Trough (Liu et al. 2003). Similar cross-shelf transport has also been observed near the depocenter off Cape Hatteras on the east coast of the US (DeMaster et al. 1994), where the circulation pattern known as the "Hatteras funnel" is responsible for the seaward export of particulate matter (Rhoads and Hecker 1994). Taken together, there are possibilities that both Taiwan mud and China's coastal mud make contributions to the sediment burial in the southern Okinawa Trough (Hung et al. 1999; Kao et al. 2003; Lee et al. 2004). The SOT has high sedimentation rates from 100 to $\left.400 \mathrm{mg} \mathrm{cm}^{-2} \mathrm{y}^{-1}\right)$, which is around 10 -fold higher than those observed in the northern and central trough $(<10$ to $80 \mathrm{mg} \mathrm{cm}^{-2} \mathrm{y}^{-1}$; Ikehara 1995; Iseki et al. 2003).

Recently, Huh et al. (2006) used ${ }^{210} \mathrm{~Pb}$ and ${ }^{137} \mathrm{Cs}$ data and sophisticated calculations to derive a sediment burial flux of $14 \mathrm{Mt} \mathrm{y}^{-1}$ for the area below a 1000-m water depth in the southern Okinawa Trough (marked by II in Fig. 5a). Unfortunately, their calculation did not separate mud and sand burials and count those areas ranging from $200-1000 \mathrm{~m}$ in depth. According to the method described above, we expand the area (see red box Fig. 5b) to $200 \mathrm{~m}$ in depth and obtain a total sediment burial of $30 \mathrm{Mt} \mathrm{y}^{-1}$, in which mud burial is 14 $\pm 2 \mathrm{Mt} \mathrm{y}^{-1}$, and the Lanyang (River 10 in Fig. 1b) itself can contribute $4.6-7.8$ (or $6 \pm 2$ in Fig. 7) Mt of sediment per year (Table 1 and Fig. 7) to the SOT. Excluding mud from the Lanyang, such a mud burial only supports $<1 / 3$ of the missing mud delivered from the Taiwan Strait and this number will be even less if SOT received mud from China's coast.

Where does most of Taiwan's mud eventually go? In fact, aside from the coastal mud belt most areas of the East China Sea (mid to outer shelf) are covered by relic sands (Boggs et al. 1979) with low organic contents (Kao et al. 2003). Is it possible that most of the mud from western Taiwan spreads northward with the TWC (Fig. 1a) onto the huge mid-outer shelf of the East China Sea and deposits homogeneously as a minor portion in relic sediments? Grain size distribution of surface sediment samples on the East China Sea shelf shows that mud may exist even in very coarse grain sediments presenting a bimodal grain size distribution pattern (as shown by three examples in Fig. 6; data from the website of the National Center for Ocean Research, Taiwan). Though the mud fraction (4 - 12 $\phi$ ) occupies only several percent in total mass, yet, the huge area coverage of the middle to outer shelf area can hold notable amounts of mud. Whether the fine-grained fraction is also relic like the sand portion warrants further tracer studies such as ${ }^{14} \mathrm{C}$ of organic carbon. Alternatively, most of the fine grains may be carried out of the strait and sucked into the Kuroshio Current (as indicated by drifter trajectory), dispersing far away and never being deposited in the East China Sea or in the southern Okinawa Trough. 

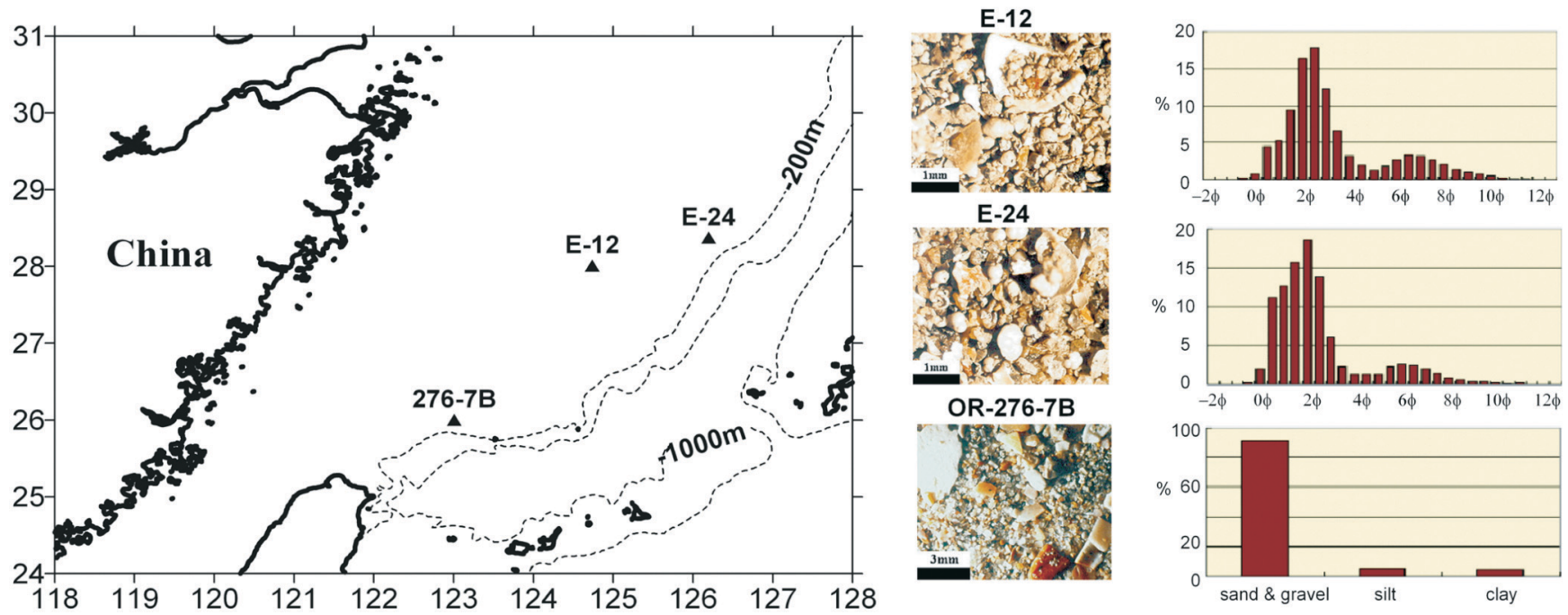

Fig. 6. Three examples of grain size distribution in surface sediments on the East China Sea shelf. Images and grain size distribution plots are downloaded from the open website of the National Center for Ocean Research, Taiwan (http://www.ncor.ntu.edu.tw/). Note that grain size is in unit of $\phi$.

As for the mud patches in the Kaoping Canyon off southwest Taiwan, where the narrow shelf and canyon systems allow fast transportation of fluvial fine-grained sediments to deep slopes. Kao et al. (2006) estimated that $\sim 50 \%$ of fluvial sediment input from Kaoping $\left(17 \pm 5 \mathrm{Mt} \mathrm{y}^{-1}\right.$; River 9 in Fig. 1b) was deposited within $120 \mathrm{~km}$ of the river mouth $\left(9 \pm 4 \mathrm{Mt} \mathrm{y}^{-1}\right.$ in Area I in Fig. 5a) with another $50 \%$ of terrestrial sediments being dispersed farther away. If sediments delivered by the Kaoping River were also dispersed into the TS through the PHC, the budget imbalance would be elevated further. More recently, based on ${ }^{137} \mathrm{Cs}$ and ${ }^{210} \mathrm{~Pb}$ data in 97 cores collected from Kaoping slope Huh et al. (2008) give a sediment burial of $6.6 \mathrm{Mt} \mathrm{y}^{-1}$ for the red area I (area slightly smaller compared to black one in Fig. 7). Their calculated budget, coupled with the presence of ${ }^{7} \mathrm{Be}$ and non-steady-state distribution of low levels of ${ }^{210} \mathrm{~Pb}$ in sediments along the canyon floor, suggests rapid sediment transport through the Kaoping Canyon and adjacent channels (as the conduit and temporary sink) to the abyssal plain and the Manila Trench in the South China Sea.

Though the input from River 9 (Kaoping River) exceeds the burial in Area I we can not exclude deposition of missing mud outside the budget area since budget calculation is area-dependent. Either Huh et al. (2008)'s or Kao et al. (2006)'s budget calculation covers a limited area thus only giving a reference.

Recently, hyperpycnal flows have drawn attention because such flows generally accompany unique transportation processes. A hyperpycnal flow is defined as a negatively buoyant fluvial discharge, resulting from high concentrations of suspended sediments that are denser than the oceanic waters into which they are discharged (see Mulder and Syvitski 1995; Mulder et al. 2003). Fluvial waters with sediment concentrations of $\sim 36-43 \mathrm{~g}^{-1}$ will produce hy- perpycnal flows although laboratory experiments suggest that concentrations as dilute as $1 \mathrm{~g} \mathrm{l}^{-1}$ may form a hyperpycnal flow (its occurrence is determined by water temperature and the salinity of oceanic coastal waters, see Table 1 in Mulder and Syvitski 1995 and Parsons et al. 2001). Our observations on sediment concentration suggest that very possibly hyperpycnal flows have occurred during typhoon floods. Behaviors of hyperpycnal flows remain unclear due to difficulties on in-situ field observations. However, numerical modeling and experimental works (Khan et al. 2005 and reference therein) point out that current speed, direction, and the seafloor slope are important factors determining its discharge. Additionally, recent modeling has shown that a turbidity current can move in an opposite direction from the overlying current as the two flows often decouple during a serious hyperpycnal flood. Accordingly, we cannot exclude the possibility of an inverse hyperpycnal flow moving through the PHC toward the south against the northward current. Without sufficient information at present and limited coverage of our budget area around the Kaoping Canyon it seems imprudent to speculate further. No matter where and how the mud from the Kaoping River deposits this issue does not affect the fact that mud imbalance exists in the Taiwan Strait.

Since the major portion of suspended sediments from western Taiwan rivers is missing more investigations are required to unravel their fate, transport, and final sinks over a different temporal and spatial scale. Applications of highresolution geophysical tools such as the high-resolution multi-channel seismic system, side-scan sonar, and chirp sonar on a regional scale survey may help us understand the large scale sediment distribution, deposition, and sediment structure, and hopefully reveal the paths of sediment transportation and burial in seas around Taiwan. 


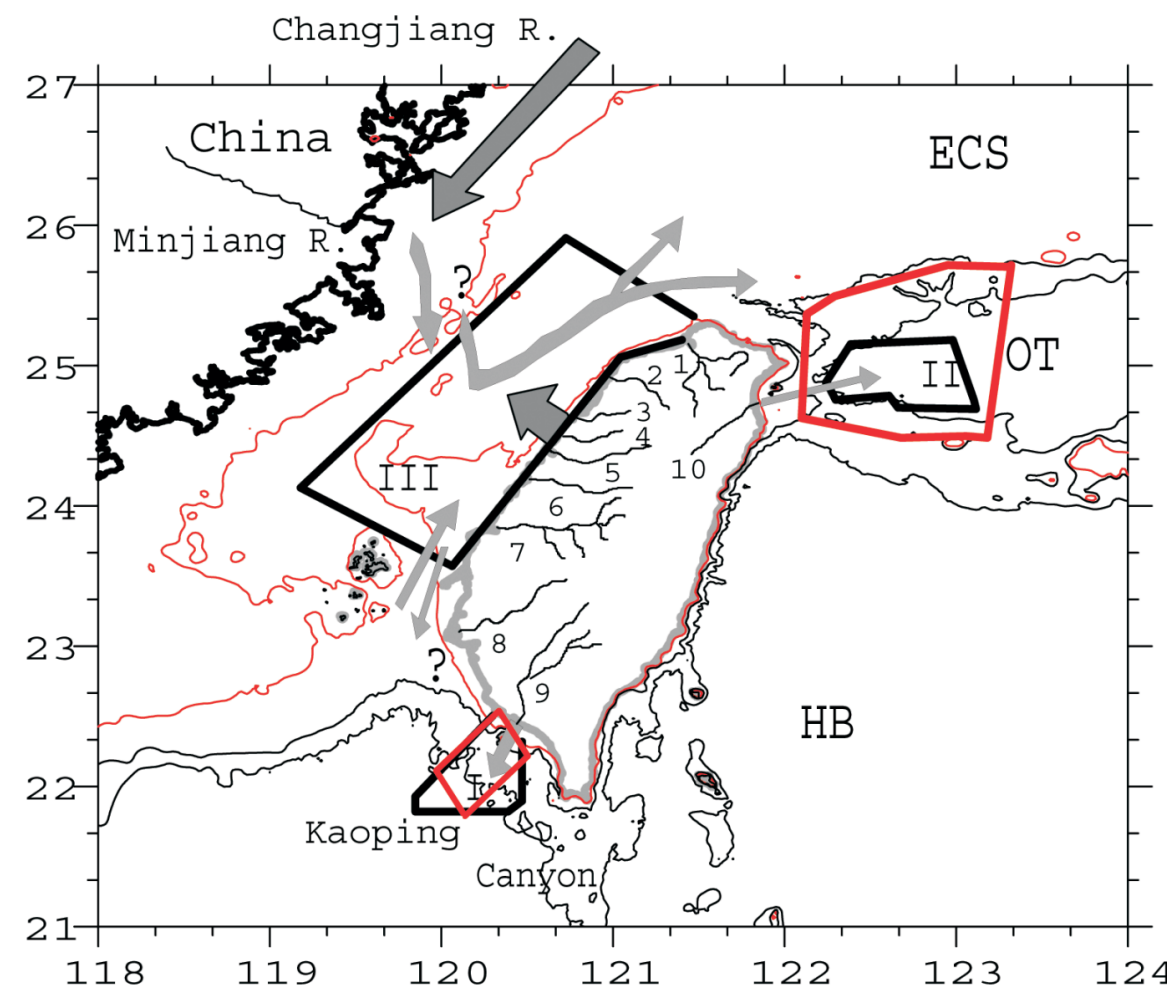

\begin{tabular}{|c|c|c|c|c|}
\hline Target area & Input River & Input (Mt/y) & Burial (Mt/y) & Reference \\
\hline I (black area) & R. 9 & $17 \pm 5$ (bulk) & $9 \pm 4$ (bulk) & Kao et al. (2006) \\
\hline I (red area) & R. 9 & & 6.6 (bulk) & Huh et al. (2008) \\
\hline II (black box) & R. 10 & $6 \pm 2$ (bulk) & 14 (bulk) & Huh et al. (2006) \\
\hline II (Red box) & R. 10 & $6 \pm 2$ (bulk) & $\begin{array}{l}16 \pm 2(\mathrm{mud}) \\
14 \pm 2(\text { sand })\end{array}$ & $\begin{array}{l}\text { This Study } \\
(\text { depth }>200 \mathrm{~m})\end{array}$ \\
\hline \multirow[t]{4}{*}{ III } & R. $1-7$ & $\begin{array}{l}42 \pm 11(\mathrm{mud}) \\
18 \pm 5(\text { sand })\end{array}$ & & \\
\hline & $\begin{array}{l}\text { R. } 8 \text { and } \\
\text { nearby rivers }\end{array}$ & $\begin{array}{l}\sim 30 \text { (bulk, } \\
\text { contribution, } \\
\text { unknown) }\end{array}$ & $\begin{array}{l}6 \pm 5(\text { mud }) \\
12 \pm 10(\text { sand })\end{array}$ & This study \\
\hline & Changjiang & unknown & & \\
\hline & Minjiang & unknown & & \\
\hline
\end{tabular}

Fig. 7. Summarized potential sources and input-output fluxes in studied areas surrounding Taiwan. Question marks indicate unknown fraction or amount of sediments from specific sources. The burial fluxes in red and black boxed are referred from listed sources.

On the other hand, some researchers (J. P. Liu, J. D. Milliman, and $\mathrm{K}$. Xu; pers. Comm.) are trying to define the fractional contribution from the Choshui River to the mud patch in the central TS and even to China's coastal mud belt by using clay mineral composition. Here in this paper, we prefer off-shelf transport from inner to outer shelf, which is better supported by sediment trap experiments and numerical model outputs in the East China Sea (Yanagi et al. 1996; Iseki et al. 2003; Oguri et al. 2003).

In the end, it is possible that our assumption of persis- tently high erosion over thousands years is not true. We clearly know that the sediment yields of most Taiwanese rivers have been enhanced by human activity. Those sediment fluxes calculated based on 50-year data might be too high to represent sediment fluxes in the pre-Anthropothene. We need more radiogenic tracer studies to ensure the input term, that is, soil erosion and trapping in river channels.

With recent work suggesting an increasing western Pacific cyclone frequency (Wu et al. 2005), Taiwan and other portions of East Asia are now experiencing a greater 
influence of typhoons. This increased typhoon activity may exacerbate current sediment delivery loads and potentially enhance carbon sequestration and affect biogeochemistry in near shore mud and deep sea clay, which occurs as a result of climate fluctuations. This implies that fundamental information from source to sink of sediments is urgently needed.

\section{SUMMARY}

Mud and sand concentrations monitored during flash floods indicate that fluvial materials in Taiwanese rivers are chiefly composed of mud $(\sim 70 \%)$, which contradicts the fact that sea surface sediments in the Taiwan Strait are dominated by sand. Pre- and post-typhoon sediment investigations indicate that wave, tide and current conditions prevent finegrained sediment deposition in shallow coastal zones. The significant shortfall in mud burial suggests $>85 \%\left(>35 \mathrm{Mt} \mathrm{y}^{-1}\right)$ of the fluvial mud, which is a good carrier for pollutants, goes somewhere outside of the strait. The imbalance is likely larger due to extra inputs from mud along the China coast and from southwestern Taiwan rivers through the PHC. Summarized potential input and output burials in Fig. 7 reveal that the SOT area accounts for only less than $1 / 3$ of the missing mud off the Taiwan Strait. Hydrodynamic conditions reveal that the missing mud sourced from western Taiwan rivers very possibly: 1) diffuses northward spreading into the large East China Sea Shelf or 2) is sucked by the year-round cyclonic eddy and then dispersed away by the Kuroshio Current. Such huge amounts of fluvial sediments from Taiwan may have significant impacts on the biogeochemistry in the East China Sea and seas surrounding Taiwan. However, in the budget calculation we cannot exclude the possibility that input sediment fluxes from land had been enhanced in the past 50 years; which means we may have had lower sediment fluxes during pre-Anthropothene. Further investigations regarding sediment source and sink are urgently needed.

Acknowledgements This study was supported by grant NSC 94-2611-M-001-004 from the National Science Council of the Republic of China. We thank J. D. Milliman, J. P. Liu, and K. Xu for valuable comments to improve our work.

\section{REFERENCES}

Boggs, S. Jr., W. C. Wang, F. S. Lewis, and J. C. Chen, 1979: Sediment properties and water characteristics of the Taiwan shelf and slope. Acta Oceanogr. Taiwan., 10, 10-49.

Chen, M. P. and M. Covey, 1983: Radiocarbon dating of pistion cored sediments from the Taiwan Strait: Preliminary results. Acta Oceanogr. Taiwan., 10, 9-15.

Chen, M. P. and T. C. Leu, 1984: Paleomagnetic inclination variations in Taiwan Strait sediments after Holocene transgression. Acta Oceanogr. Taiwan., 15, 53-70.
Chen, M. P., Y. T. Shieh, and J. M. Chyan, 1988: Acoustic and physical properties of surface sediments in northern Taiwan Strait. Acta Oceanogr. Taiwan., 21, 92-118.

Chen, W. C. and C. T. Lin, 1997a: Marine sediment resources in the Taiwan Strait. Central Geological Survey Special Publication, No. 9, 1-46, Central Geological Survey, MOEA, Taipei, Taiwan. (in Chinese)

Chen, W. C., C. T. Lin, J. S. Chen, and R. C. Kao, 1997b: Marine sediment resources off the Tongshao-Shengang coast. Central Geological Survey Special Publication, No. 9, 47-76, Central Geological Survey, MOEA, Taipei, Taiwan. (In Chinese)

Chen, W. C., C. T. Lin, and R. C. Chen, 1997c: Marine sediment resources off the Chunan-Shianshan coast. Central Geological Survey Special Publication, No. 9, 77-106, Central Geological Survey, MOEA, Taipei, Taiwan. (In Chinese)

Chen, Y. C., 1997d: Sedimentology of surface sediments off Southwest Taiwan. Ph.D. Thesis, National Taiwan Univsersity, Taiwan, ROC, $180 \mathrm{pp}$.

Chung, Y. C. and W. C. Chang, 1995: ${ }^{210} \mathrm{~Pb}$ fluxes and sedimentation rates on the lower continental slope between Taiwan and the South Okinawa Trough. Cont. Shelf Res., 15, 149-164.

Dadson, S. J., N. Hovius, H. Chen, W. B. Dade, M. L. Hsieh, S. D. Willett, J. C. Hu, M. J. Horng, M. C. Chen, C. P. Stark, D. Lague, and J. C. Lin, 2003: Links between erosion, runoff variability and seismicity in the Taiwan orogen. $\mathrm{Na}$ ture, 426, 648-651.

Dadson, S. J., N. Hovius, H. Chen, W. B. Dade, J. C. Lin, M. L. Hsu, C. W. Lin, M. J. Horng, T. C. Chen, J. D. Milliman, and C. P. Stark, 2004: Earthquake-triggered increase in sediment delivery from an active mountain belt. Geology, 32, 733-736.

DeMaster, D., R. H. Pope, L. A. Levin, and N. E. Blair, 1994: Biological mixing intensity and rates of organic carbon accumulation in North Carolina slope sediments. DeepSea Res. II, 41, 735-754.

Deng, B., J. Zhang, and Y. Wu, 2006: Recent sediment accumulation and carbon burial in the East China Sea. Global Biogeochem. Cycles, 20, GB3014.

Fang, T. H. and E. Hong, 1999: Mechanisms influencing the spatial distribution of trace metals in surficial sediments off the south-western Taiwan. Mar. Pollut. Bull., 38, 1026-1037.

Guan, B., 1994: Patterns and structures of the currents in Bohai, Huanghai and East China Seas. In: Zhao, D., Y. B. Liang, C. K. Zeng (Eds.), Oceanology of China Seas, Vol. 1, Kluwer Academic Publishers, Dordrecht, Netherlands, 17-26.

Hedges, J. I. and R. G. Keil, 1995: Sedimentary organic matter preservation: An assessment and speculative synthesis. Mar. Chem., 49, 81-115.

Hong, E., T. C. Huang, and H. S. Yu, 2004: Morphology and dynamic sedimentology in front of the retreating Tseng- 
wen Delta, southwestern Taiwan. Terr. Atmos. Ocean. Sci., 15, 565-587.

Hovius, N., C. P. Stark, H. T. Chu, and J. C. Lin, 2000: Supply and removal of sediment in a landslide-dominated mountain belt: Central Range, Taiwan. J. Geol., 108, 73-89.

Hu, D., Y. Saito, and S. Kempe, 1998: Sediment and nutrient transport to the coastal zone. In: Galloway, J. N. and J. M. Melillo (Eds.), Asia Change in the Context of Global Climate Change, IGBP book series, Cambridge University Press, 245-270.

Huang, Q., W. Wang, Y. S. Li, and C. W. Li, 1994: Current characteristics of the South China Sea. In: Zhao, D., Y. B. Liang, C. K. Zeng (Eds.), Oceanology of China Seas, Vol. 1, Kluwer Academic Publishers, Dordrecht, Netherlands, 17-26.

Huang, Z. Y. and H. S. Yu, 2003: Morphology and geologic implication of Penghu Channel off southwest Taiwan. Terr. Atmos. Ocean. Sci., 14, 469-485.

Huh, C. A. and C. C. Su, 1999: Sedimentation dynamics in the East China Sea elucidated from ${ }^{210} \mathrm{~Pb},{ }^{137} \mathrm{Cs}$ and ${ }^{239,}{ }^{240} \mathrm{Pu}$. Mar. Geol., 160, 183-196.

Huh, C. A., C. C. Su, C. H. Wang, S. Y. Lee, and I. T. Lin, 2006: Sedimentation in the southern Okinawa Troughrates, turbidites and a sediment budget. Mar. Geol., 231, 129-139.

Huh, C. A., H. L. Lin, S. Lin, and Y. W. Huang, 2008: Modern accumulation rates and a budget of sediment off the Kaoping River, SW Taiwan: A tidal and flood dominated depositional environment around a submarine canyon. $J$. Mar. Syst. (in press)

Hung, J. J., C. S. Lin, G. W. Hung, and Y. C. Chung, 1999: Lateral transport of lithogenic particles from the continental margin of the southern East China Sea. Estuar. Coast. Shelf Sci., 49, 483-499.

Ikehara, K., 1995: Depositional pattern of the Okinawa Trough as revealed by $3.5 \mathrm{kHz}$ sub-bottom profiler and cored data. In: Tsunogai, S. et al. (Eds.), Global Fluxes of Carbon and Its Related Substances in the Coastal Sea-Ocean-Atmosphere System, 26-31, Yokohama, Japan M. \& J. International.

Iseki, K., K. Okamura, and Y. Kiyomoto, 2003: Seasonality and composition of downward particulate fluxes at the continental shelf and Okinawa Trough in the East China Sea. Deep-Sea Res. II, 50, 457-473.

Jan, S. and S. Y. Chao, 2003: Seasonal variation of volume transport in the major inflow region of the Taiwan Strait: The Penghu Channel. Dee-Sea Res. II, 50, 1117-1126.

Jan, S., J. Wang, C. S. Chern, and S. Y. Chao, 2002: Seasonal variation of the circulation in the Taiwan Strait. J. Mar. Syst., 35, 249-168.

Jan, S., C. S. Chern, J. Wang, and S. Y. Chao, 2004: The anomalous amplification of M-2 tide in the Taiwan Strait. Geophys. Res. Lett., 31, L07308. doi: 10.1029/2003GL019373.

Kao, S. J. and K. K. Liu, 1996: Particulate organic carbon ex- port from a subtropical mountainous river (Lanyang-Hsi) in Taiwan. Limnol. Oceanogr., 41, 1749-1757.

Kao, S. J. and K. K. Liu, 2001: Estimating the suspended sediment load by using the historical hydrometric record from the Lanyang-Hsi watershed. Terr. Atmos. Ocean. Sci., 12, 401-414.

Kao, S. J. and K. K. Liu, 2002: Exacerbation of erosion induced by human perturbation in a typical Oceania watershed: Insight from 45 years of hydrological records from the Lanyang-Hsi River, northeastern Taiwan. Global Biogeochem. Cycles, 16, doi: 10.1029/2000GB001334.

Kao, S. J. and J. D. Milliman, 2008: Characterize sediment and water discharges from high standing island rivers in Taiwan: Episodicity and human activities. J. Geol. (in press)

Kao, S. J., F. J. Lin, and K. K. Liu, 2003: Organic carbon and nitrogen contents and their isotopic compositions in surficial sediments from the East China Sea shelf and the Okinawa Trough. Deep-Sea Res. II, 50, 1203-1217.

Kao, S. J., T. Y. Lee, and J. D. Milliman, 2005: Calculating highly fluctuated suspended sediment fluxes from mountainous rivers in Taiwan. Terr. Atmos. Ocean. Sci., 16, 653-675.

Kao, S. J., F. K. Shiah, C. H. Wang, and K. K. Liu, 2006: Efficient trapping of organic carbon in sediments on the continental margin with high fluvial sediment input off southwestern Taiwan. Cont. Shelf Res., 26, 2520-2537.

Keil, R. G., E. C. Tsamakis, C. B. Fuh, J. C. Giddings, and J. I. Hedges, 1994: Mineralogical and texture controls on the organic composition of coastal marine sediments: Hydrodynamic separation using SPLITT-fractionation. Geochem. et Cosmochim. Acta, 58, 879-893.

Khan, S. M., J. Imran, S. Bradford, and J. P. M. Syvitski, 2005: Numerical modeling of hyperpycnal plume. Mar. Geol., 222-223, 193-211, doi: 10.1016/j.margeo.2005.06.025.

Lee, H. J. and S. Y. Chao, 2003: A climatological description of circulation in and around the East China Sea. Deep-Sea Res. II, 50, 1065-1084.

Lee, S. Y., C. A. Huh, C. C. Su, and C. F. You, 2004: Sedimentation in the Southern Okinawa Trough: Enhanced particle scavenging and teleconnection between the Equatorial Pacific and western Pacific margins. Deep-Sea Res. I, 51, 1769-1780.

Lee, T., C. F. You, and T. K. Liu, 1993: Model-dependent ${ }^{10}$ Be sedimentation rates for the Taiwan Strait and their tectonic significance. Geology, 21, 423-426.

Li, Y. H., 1976: Denudation of Taiwan Island since the Pleistocene epoch. Geology, 4, 105-107.

Lin, S., K. M. Huang, and S. K. Chen, 2000: Organic carbon deposition and its control on iron sulfide formation of the southern East China Sea continental shelf sediments. Cont. Shelf Res., 20, 619-635.

Lin, S., I. J. Hsieh, K. M. Huang, and C. H. Wang, 2002: Influence of the Yangtze River and grain size on the spatial 
variations of heavy metals and organic carbon in the East China Sea continental shelf sediments. Chem. Geol., 182, 377-394.

Liu, J. P., K. H. Xu, A. C. Li, J. D. Milliman, D. M. Velozzi, S. B. Xiao, and Z. S. Yang, 2007: Flux and fate of Yangtze River sediment delivered to the East China Sea. Geomorphology, 85, 208-224.

Liu, J. T., J. S. Huang, R. T. Hsu, and J. M. Chyan, 2000: The coastal depositional system of a small mountainous river: A perspective from grain-size distributions. Mar. Geol., 165, 63-86.

Liu, K. K., T. H. Peng, P. T. Shaw, and F. K. Shiah, 2003: Circulation and biogeochemical processes in the East China Sea and the vicinity of Taiwan: An overview and a brief synthesis. Deep-Sea Res. II, 50, 1055-1064.

Lyons, W. B., C. A. Nezat, A. E. Carey, and D. M. Hicks, 2002: Organic carbon fluxes to the ocean from high-standing islands. Geology, 30, 443-446.

Mayer, L. M., 1994: Surface area control of organic carbon accumulation in the continental shelf sediments. Geochim. Cosmochim. Acta, 58, 1271-1284.

Milliman, J. D. and R. H. Meade, 1983: World-wide delivery of river sediment to the oceans. J. Geol., 91, 1-21.

Milliman, J. D. and J. P. M. Syvitski, 1992: Geomorphic/tectonic control of sediment discharge to the ocean: The importance of small mountainous rivers. J. Geol., 100, 525-544.

Milliman, J. D. and S. J. Kao, 2005: Hyperpycnal discharge of fluvial sediment to the ocean: Impact of super-typhoon Herb (1996) on Taiwanese rivers. J. Geol., 113, 503-516.

Milliman, J. D., H. T. Shen, Z. S. Yang, and R. H. Meade, 1985: Transport and deposition of river sediment in the Changjiang estuary and adjacent continental shelf. Cont. Shelf Res., 4, 37-45.

Mulder, T. and J. P. M. Syvitski, 1995: Turbidity currents generated at river mouths during exceptional discharges to the world oceans. J. Geol., 103, 285-299.

Mulder, T., J. P. M. Syvitski, S. Migeon, J. C. Faugere, and B. Savoye, 2003: Marine hyperpycnal flows: Initiation, behavior and related deposits, A review. Mar. Petrol. Geol., 20, $861-882$.

Nitani, H., 1972: Beginning of the Kuroshio. In: Stommel, H., K. Yoshida (Eds.), Kuroshio, Its Physical Aspects, University of Tokyo Press, Tokyo, Japan, 129-163.

Oguri, K., E. Matsumoto, M. Yamada, Y. Saito, and K. Iseki, 2003: Sediment accumulation rates and budgets of depositing particles of the East China Sea. Deep-Sea Res. II, 50, 513-528.

Parsons, J. D., J. W. Bush, and J. P. M. Syvitski, 2001: Hyperpycnal plume formation from riverine outflows with small sediment concentrations. Sedimentology, 48, 465-478.

Phillips, D. L. and D. G. Marks, 1996: Spatial uncertainty analysis: Propagation of interpolation errors in spatially distributed models. Ecol. Model., 91, 213-229.

Rhoads, D. D. and R. B. Hecke, 1994: Processes on the continental slope off North Carolina with special reference to the Cape Hatteras region. Deep-Sea Res. II, 41, $965-$ 980 .

Syvitski, J. P. M. and J. D. Milliman, 2007: Geology, geography, and humans battle for dominance over the delivery of fluvial sediment to the coastal ocean. J. Geol., 115, 1-19.

Syvitski, J. P. M., C. Vörösmarty, A. J. Kettner, and P. Green, 2005a: Impact of humans on the flux of terrestrial sediment to the global coastal ocean. Science, 308, 376-380.

Syvitski, J. P. M, A. J. Kettner, S. D. Peckham, and S. J. Kao, 2005b: Predicting the flux of sediment to the coastal zone: Application to the Lanyang watershed, northern Taiwan. $J$. Coast. Res., 21, 580-587.

Thomas, H., Y. Bozec, K. Elkalay, and H. K.W. Baar, 2004: Enhanced open ocean storage of $\mathrm{CO}_{2}$ from shelf sea pumping. Science, 304, 1005-1008.

Tseng, R. S. and Y. T. Shen, 2003: Lagrangian observations of surface flow pattern in the vicinity of Taiwan. Deep-Sea Res. II, 50, 1107-1115.

Wang, H., Z. Yang, Y. Saito, J. P. Liu, X. Sun, and Y. Wang, 2007: Stepwise decreases of the Huanghe (Yellow River) sediment load (1950-2005): Impacts of climate change and human activities. Global Planet. Change, 57, 331-354.

Willett, S. D., D. Fisher, C. Fuller, Y. En-Chao, and C. Y. Lu, 2003: Erosion rates and orogenic-wedge kinematics in Taiwan inferred from fission-track thermochronometry. Geology, 31, 945-948.

Wu, L., B. Wang, and S. Geng, 2005: Growing typhoon influence on East Asia. Geophys. Res. Lett., 32, L18703, doi: 10.1029/2005GL022937.

Xu, K., J. D. Milliman, Z. Yang, and H. Wang, 2006: Yangtze sediment decline partly from Three Gorges Dam. EOS Trans. $A G U, \mathbf{8 7}, 185-196$.

Xu, Z, M. Wang, A. Hong, F. Guo, and G. Liu, 1989: Ages of sediments and sedimentation rates of the western Taiwan Strait since late Pleistocene. J. Oceanogr. Taiwan Strait, 8, 114-122. (In Chinese)

Xu, Z, M. Wang, A. Hong, and F. Guo, 1990: The sedimentary age of the sand bar in the Minjiang Estuary and its evolution. J. Oceanogr. Taiwan Strait, 9, 30-33. (In Chinese)

Yanagi, T., S. Takahashi, A. Hoshika, and T. Tanimoto, 1996: Seasonal variation in the transport of suspended matter in the East China Sea. J. Oceanogr., 52, 539-552.

Yuan, D., H. Cheng, R. L. Edwards, C. A. Dykoski, M. J. Kelly, M. Zhang, J. Qing, Y. Lin, Y. Wang, J. Wu, J. A. Dorale, Z. An, and Y. Cai, 2004: Timing, Duration, and Transitions of the Last Interglacial Asian Monsoon. Science, 304, 575578.

Zhao, Y. and M. Yan, 1994: Geochemistry of sediments of the China Shelf Sea. Science Press, Beijing, China, 203 pp. (in Chinese) 


\section{APPENDIX}

Appendix 1. Data for sediment collected on three rivers during typhoon invasion.

\begin{tabular}{|c|c|c|c|c|c|c|c|}
\hline \multicolumn{8}{|c|}{ Danshui River-Typhoon Billis } \\
\hline Year & Month & Date & Time & Hrs* & $\mathrm{Q}(\mathrm{cms})$ & $\operatorname{TSM}\left(\mathrm{g} \mathrm{L}^{-1}\right)$ & Mud (\%) \\
\hline 2000 & 8 & 22 & 1330 & 23 & 323 & 0.076 & 95 \\
\hline 2000 & 8 & 22 & 1530 & 25 & 343 & 0.049 & 94 \\
\hline 2000 & 8 & 22 & 1740 & 27 & 587 & 0.080 & 96 \\
\hline 2000 & 8 & 22 & 2030 & 30 & 1384 & 0.454 & 95 \\
\hline 2000 & 8 & 22 & 2250 & 32 & 1807 & 1.469 & 90 \\
\hline 2000 & 8 & 23 & 1300 & 35 & 3033 & 5.226 & 86 \\
\hline 2000 & 8 & 23 & 0530 & 39 & 2320 & 4.262 & 89 \\
\hline 2000 & 8 & 23 & 0900 & 42 & 1882 & 4.319 & 87 \\
\hline 2000 & 8 & 23 & 1330 & 47 & 1914 & 2.537 & 92 \\
\hline 2000 & 8 & 23 & 1800 & 51 & 1704 & 1.449 & 95 \\
\hline 2000 & 8 & 24 & 0945 & 67 & 807 & 1.040 & 96 \\
\hline 2000 & 8 & 24 & 1820 & 76 & 577 & 0.612 & 92 \\
\hline \multicolumn{8}{|c|}{ Lanyang River-Typhoon Tim } \\
\hline Year & Month & Date & Time & Hrs* & $\mathrm{Q}(\mathrm{cms})$ & $\operatorname{TSM}\left(\mathrm{g} \mathrm{L}^{-1}\right)$ & Mud (\%) \\
\hline 1994 & 7 & 10 & 1030 & 35 & 50 & 0.372 & 95 \\
\hline 1994 & 7 & 10 & 1530 & 40 & 63 & 0.350 & 92 \\
\hline 1994 & 7 & 10 & 2000 & 44 & 112 & 0.716 & 94 \\
\hline 1994 & 7 & 11 & 0300 & 51 & 2950 & 24.536 & 75 \\
\hline 1994 & 7 & 11 & 0800 & 56 & 1800 & 8.200 & 82 \\
\hline 1994 & 7 & 11 & 1230 & 61 & 1280 & 7.680 & 95 \\
\hline 1994 & 7 & 11 & 1600 & 64 & 978 & 5.560 & 92 \\
\hline 1994 & 7 & 11 & 2000 & 68 & 684 & 5.300 & 84 \\
\hline 1994 & 7 & 11 & 2400 & 72 & 551 & 12.816 & 82 \\
\hline 1994 & 7 & 12 & 0600 & 78 & 467 & 11.420 & 92 \\
\hline 1994 & 7 & 12 & 1000 & 82 & 448 & 9.805 & 87 \\
\hline \multicolumn{8}{|c|}{ Choshui River-Typhoon Mindulle } \\
\hline Year & Month & Date & Time & Hrs* & $\mathrm{Q}(\mathrm{cms})$ & $\operatorname{TSM}\left(\mathrm{g} \mathrm{L}^{-1}\right)$ & Mud (\%) \\
\hline 2004 & 6 & 24 & 1225 & 391 & 21 & 0.433 & 81 \\
\hline 2004 & 6 & 28 & 1710 & 504 & 12 & 1.053 & 80 \\
\hline 2004 & 6 & 30 & 1645 & 552 & 44 & 0.866 & 89 \\
\hline 2004 & 7 & 1 & 0600 & 565 & 54 & 1.959 & 82 \\
\hline 2004 & 7 & 1 & 1157 & 571 & 72 & 3.952 & 90 \\
\hline 2004 & 7 & 1 & 1455 & 574 & 62 & 4.691 & 86 \\
\hline 2004 & 7 & 1 & 1759 & 577 & 180 & 58.286 & 87 \\
\hline 2004 & 7 & 1 & 2104 & 580 & 416 & 43.836 & 85 \\
\hline 2004 & 7 & 2 & 0006 & 583 & 432 & 34.592 & 86 \\
\hline 2004 & 7 & 2 & 0305 & 586 & 510 & 31.571 & 78 \\
\hline 2004 & 7 & 2 & 0604 & 589 & 664 & 53.442 & 82 \\
\hline
\end{tabular}


Appendix 1. (Continued)

\begin{tabular}{|c|c|c|c|c|c|c|c|}
\hline Year & Month & Date & Time & Hrs* & $\mathrm{Q}(\mathrm{cms})$ & $\operatorname{TSM}\left(\mathrm{g} \mathrm{L}^{-1}\right)$ & Mud (\%) \\
\hline 2004 & 7 & 2 & 0904 & 592 & 692 & 37.323 & 83 \\
\hline 2004 & 7 & 2 & 1205 & 595 & 804 & 38.419 & 82 \\
\hline 2004 & 7 & 2 & 1500 & 598 & 1496 & 32.981 & 80 \\
\hline 2004 & 7 & 2 & 1830 & 602 & 2600 & 59.991 & 75 \\
\hline 2004 & 7 & 2 & 2056 & 604 & 2100 & 95.005 & 66 \\
\hline 2004 & 7 & 3 & 0000 & 607 & 2120 & 93.848 & 55 \\
\hline 2004 & 7 & 3 & 0315 & 610 & 2300 & 92.365 & 53 \\
\hline 2004 & 7 & 3 & 0600 & 613 & 3200 & 199.663 & 75 \\
\hline 2004 & 7 & 3 & 0912 & 616 & 3200 & 190.449 & 48 \\
\hline 2004 & 7 & 3 & 1214 & 619 & 2520 & 125.937 & 61 \\
\hline 2004 & 7 & 3 & 1504 & 622 & 2120 & 100.233 & 59 \\
\hline 2004 & 7 & 3 & 1810 & 625 & 1920 & 70.112 & 65 \\
\hline 2004 & 7 & 3 & 2110 & 628 & 2120 & 92.452 & 52 \\
\hline 2004 & 7 & 4 & 0011 & 631 & 1544 & 76.785 & 57 \\
\hline 2004 & 7 & 4 & 0313 & 634 & 1128 & 61.453 & 61 \\
\hline 2004 & 7 & 4 & 0617 & 637 & 1640 & 107.168 & 48 \\
\hline 2004 & 7 & 4 & 0940 & 641 & 3200 & 73.610 & 61 \\
\hline 2004 & 7 & 4 & 1205 & 643 & 6390 & 105.049 & 55 \\
\hline 2004 & 7 & 5 & 1610 & 671 & 2060 & 20.417 & 80 \\
\hline 2004 & 7 & 6 & 1730 & 697 & 1180 & 30.464 & 75 \\
\hline
\end{tabular}

* Hrs represents the continuous sampling hour in Fig. 3.

Appendix 2. Mud fraction in surface sediments from the river mouth of Choshui in 1996 and 1997.

\begin{tabular}{ccccc}
\hline Sta. & long. (oE) & lat. (oN) & 96-Mud\% & 97-Mud\% \\
\hline sec 1.01 & 120.2461 & 23.8951 & 1 & 1 \\
sec 1.03 & 120.2452 & 23.8962 & 1 & 1 \\
sec 1.05 & 120.2407 & 23.9002 & 63 & 2 \\
sec 1.75 & 120.2346 & 23.9042 & 58 & 10 \\
sec 1.10 & 120.2300 & 23.9070 & 10 & 6 \\
sec 1.15 & 120.2245 & 23.9118 & 7 & 11 \\
sec 1.20 & 120.2094 & 23.9217 & 37 & 22 \\
sec 1.30 & 120.1963 & 23.9283 & 40 & 47 \\
sec 1.H & 120.2788 & 23.8763 & 80 & 68 \\
sec 1.M & 120.2676 & 23.8834 & 82 & 85 \\
sec 1.L & 120.2596 & 23.8845 & 75 & 87 \\
sec 2.01 & 120.2252 & 23.8773 & 1 & 1 \\
sec 2.03 & 120.2240 & 23.8785 & 56 & 1 \\
sec 2.05 & 120.2199 & 23.8812 & 68 & 1 \\
sec 2.75 & 120.2170 & 23.8826 & 3 & 2 \\
sec 2.10 & 120.2150 & 23.8848 & 5 & 4 \\
\hline
\end{tabular}

\begin{tabular}{ccccc}
\hline Sta. & long. (oE) & lat. (oN) & 96-Mud\% & 97-Mud\% \\
\hline sec 2.15 & 120.2101 & 23.8877 & 4 & 6 \\
sec 2.20 & 120.2071 & 23.8909 & 8 & 7 \\
sec 2.30 & 120.1713 & 23.9132 & 60 & 71 \\
sec 2.H & 120.2541 & 23.8631 & 28 & 13 \\
sec 2.M & 120.2438 & 23.8661 & 27 & 37 \\
sec 2.L & 120.2339 & 23.8701 & 20 & 56 \\
sec 3.01 & 120.2093 & 23.8581 & 2 & 1 \\
sec 3.03 & 120.2080 & 23.8591 & 4 & 2 \\
sec 3.05 & 120.2064 & 23.8597 & 3 & 2 \\
sec 3-75 & 120.2050 & 23.8604 & 3 & 1 \\
sec 3.10 & 120.2030 & 23.8630 & 67 & 2 \\
sec 3-15 & 120.1984 & 23.8655 & 10 & 5 \\
sec 3.20 & 120.1962 & 23.8662 & 69 & 7 \\
sec 3.30 & 120.1554 & 23.8946 & 3 & 20 \\
sec 4.01 & 120.1950 & 23.8314 & 1 & 1 \\
sec 4.03 & 120.1914 & 23.8319 & 15 & 2 \\
\hline
\end{tabular}


Appendix 2. (Continued)

\begin{tabular}{|c|c|c|c|c|c|c|c|c|c|}
\hline Sta. & long. (oE) & lat. $(\mathrm{oN})$ & 96-Mud\% & 97-Mud\% & Sta. & long. (oE) & lat. $(\mathrm{oN})$ & 96-Mud\% & 97-Mud\% \\
\hline $\sec 4.05$ & 120.1884 & 23.8347 & 5 & 9 & sec 7.M & 120.1649 & 23.7514 & 1 & 1 \\
\hline $\sec 4.75$ & 120.1848 & 23.8373 & 90 & 7 & $\sec 7 . \mathrm{L}$ & 120.1659 & 23.7520 & 1 & 1 \\
\hline $\sec 4.10$ & 120.1819 & 23.8394 & 54 & 3 & $\sec 8.01$ & 120.1476 & 23.7325 & 4 & 3 \\
\hline $\sec 4.15$ & 120.1803 & 23.8405 & 22 & 5 & $\sec 8.03$ & 120.1432 & 23.7337 & 3 & 5 \\
\hline $\sec 4.20$ & 120.1768 & 23.8436 & 4 & 27 & $\sec 8-05$ & 120.1398 & 23.7362 & 4 & 4 \\
\hline $\sec 4-30$ & 120.1414 & 23.8661 & 1 & 6 & $\sec 8.75$ & 120.1365 & 23.7372 & 4 & 2 \\
\hline $\sec 4 . \mathrm{H}$ & 120.1980 & 23.8241 & 4 & 3 & $\sec 8.10$ & 120.1349 & 23.7385 & 3 & 2 \\
\hline $\sec 4 . M$ & 120.1964 & 23.8299 & 2 & 1 & $\sec 8.15$ & 120.1302 & 23.7415 & 5 & 49 \\
\hline $\sec 4 . \mathrm{L}$ & 120.1960 & 23.8270 & 3 & 57 & $\sec 8.20$ & 120.1053 & 23.7562 & 4 & 2 \\
\hline $\sec 5.01$ & 120.1724 & 23.8170 & 63 & 2 & $\sec 8.30$ & 120.0966 & 23.7612 & 4 & 7 \\
\hline $\sec 5.03$ & 120.1692 & 23.8181 & 3 & 1 & $\sec 8 . \mathrm{H}$ & 120.1611 & 23.7240 & 69 & 48 \\
\hline $\sec 5.05$ & 120.1677 & 23.8185 & 1 & 1 & $\sec 8 . \mathrm{M}$ & 120.1550 & 23.7278 & 63 & 78 \\
\hline $\sec 5.75$ & 120.1657 & 23.8190 & 2 & 2 & $\sec 8 . \mathrm{L}$ & 120.1523 & 23.7299 & 55 & 83 \\
\hline $\sec 5.10$ & 120.1642 & 23.8203 & 6 & 2 & $\sec 9.01$ & 120.1402 & 23.7037 & 1 & 1 \\
\hline $\sec 5.15$ & 120.1628 & 23.8205 & 3 & 6 & $\sec 9.03$ & 120.1367 & 23.7056 & 1 & 1 \\
\hline $\sec 5.20$ & 120.1607 & 23.8211 & 72 & 5 & $\sec 9.05$ & 120.1344 & 23.7073 & 5 & 3 \\
\hline $\sec 5.30$ & 120.1248 & 23.8436 & 3 & 60 & $\sec 9.75$ & 120.1295 & 23.7098 & 7 & 2 \\
\hline $\sec 5 . \mathrm{H}$ & 120.1986 & 23.7838 & 79 & 2 & sec 9.10 & 120.1184 & 23.7177 & 2 & 1 \\
\hline $\sec 5 . M$ & 120.1902 & 23.7928 & 69 & 1 & $\sec 9.15$ & 120.0983 & 23.7284 & 2 & 2 \\
\hline $\sec 5 . \mathrm{L}$ & 120.1833 & 23.8013 & 86 & 1 & $\sec 9-20$ & 120.0955 & 23.7301 & 2 & 2 \\
\hline $\sec 6.01$ & 120.1589 & 23.7877 & 44 & 83 & $\sec 9.30$ & 120.0815 & 23.7374 & 2 & 9 \\
\hline $\sec 6.03$ & 120.1556 & 23.7886 & 66 & 83 & $\sec 9 . \mathrm{H}$ & 120.1507 & 23.6835 & 1 & 3 \\
\hline $\sec 6.05$ & 120.1531 & 23.7915 & 31 & 87 & $\sec 9 . \mathrm{M}$ & 120.1458 & 23.6893 & 45 & 2 \\
\hline $\sec 6.75$ & 120.1515 & 23.7932 & 21 & 17 & $\sec 9 . \mathrm{L}$ & 120.1423 & 23.6954 & 15 & 1 \\
\hline $\sec 6.10$ & 120.1509 & 23.7941 & 3 & 4 & $\sec 10.01$ & 120.1290 & 23.6762 & 26 & 1 \\
\hline $\sec 6.15$ & 120.1511 & 23.7955 & 5 & 4 & $\sec 10.03$ & 120.1258 & 23.6775 & 2 & 1 \\
\hline $\sec 6.20$ & 120.1483 & 23.7973 & 4 & 3 & $\sec 10.05$ & 120.1234 & 23.6794 & 5 & 1 \\
\hline $\sec 6.30$ & 120.1156 & 23.8154 & 3 & 1 & sec 10.75 & 120.1196 & 23.6816 & 4 & 3 \\
\hline $\sec 6 . H$ & 120.1911 & 23.7749 & 5 & 4 & $\sec 10.10$ & 120.0998 & 23.6896 & 43 & 2 \\
\hline $\sec 6 . \mathrm{M}$ & 120.1771 & 23.7801 & 11 & 19 & $\sec 10.15$ & 120.0844 & 23.7031 & 3 & 2 \\
\hline $\sec 6 . \mathrm{L}$ & 120.1651 & 23.7879 & 54 & 58 & sec 10.20 & 120.0791 & 23.7068 & 3 & 2 \\
\hline $\sec 7.01$ & 120.1650 & 23.7512 & 1 & 2 & sec 10.30 & 120.0563 & 23.7111 & 3 & 2 \\
\hline sec 7-03 & 120.1626 & 23.7554 & 10 & 2 & $\sec 10 . \mathrm{H}$ & 120.1408 & 23.6621 & 1 & 5 \\
\hline $\sec 7.05$ & 120.1513 & 23.7600 & 2 & 3 & $\sec 10 . \mathrm{M}$ & 120.1345 & 23.6674 & 3 & 9 \\
\hline $\sec 7.75$ & 120.1495 & 23.7610 & 7 & 3 & $\sec 10 . \mathrm{L}$ & 120.1307 & 23.6717 & 5 & 2 \\
\hline $\sec 7.10$ & 120.1470 & 23.7622 & 4 & 4 & $\sec 11.01$ & 120.1151 & 23.6450 & 2 & 63 \\
\hline $\sec 7.15$ & 120.1287 & 23.7707 & 54 & 3 & $\sec 11.03$ & 120.1130 & 23.6459 & 3 & 10 \\
\hline $\sec 7.20$ & 120.1136 & 23.7831 & 4 & 3 & $\sec 11.05$ & 120.1108 & 23.6458 & 16 & 1 \\
\hline $\sec 7.30$ & 120.1010 & 23.7877 & 2 & 2 & $\sec 11.75$ & 120.1090 & 23.6468 & 2 & 2 \\
\hline $\sec 7 . \mathrm{H}$ & 120.1679 & 23.7508 & 1 & 1 & $\sec 11.10$ & 120.0930 & 23.6682 & 5 & 1 \\
\hline
\end{tabular}


Appendix 2. (Continued)

\begin{tabular}{|c|c|c|c|c|}
\hline Sta. & long. (oE) & lat. $(\mathrm{oN})$ & 96-Mud\% & 97-Mud\% \\
\hline $\sec 11.15$ & 120.0705 & 23.6809 & 3 & 1 \\
\hline $\sec 11.20$ & 120.0733 & 23.6784 & 5 & 3 \\
\hline $\sec 11.30$ & 120.0644 & 23.6828 & 3 & 28 \\
\hline $\sec 11 . \mathrm{H}$ & 120.1311 & 23.6325 & 1 & 1 \\
\hline $\sec 11 . \mathrm{M}$ & 120.1268 & 23.6346 & 5 & 9 \\
\hline $\sec 11 . \mathrm{L}$ & 120.1202 & 23.6381 & 10 & 2 \\
\hline $\sec 12.01$ & 120.1108 & 23.6285 & 1 & 22 \\
\hline $\sec 12.03$ & 120.1087 & 23.6297 & 4 & 1 \\
\hline $\sec 12.05$ & 120.0944 & 23.6332 & 1 & 3 \\
\hline $\sec 12.75$ & 120.0794 & 23.6412 & 2 & 4 \\
\hline $\sec 12.10$ & 120.0681 & 23.6450 & 5 & 5 \\
\hline $\sec 12-15$ & 120.0588 & 23.6478 & 2 & 3 \\
\hline $\sec 12.20$ & 120.0538 & 23.6511 & 6 & 2 \\
\hline $\sec 12.30$ & 120.0272 & 23.6673 & 1 & 3 \\
\hline $\sec 12 . \mathrm{H}$ & 120.1287 & 23.6259 & 10 & 16 \\
\hline $\sec 12 . \mathrm{M}$ & 120.1222 & 23.6240 & 3 & 1 \\
\hline $\sec 12 . \mathrm{L}$ & 120.1164 & 23.6258 & 3 & 1 \\
\hline $\sec 13.01$ & 120.0787 & 23.6094 & 3 & 2 \\
\hline sec 13.03 & 120.0773 & 23.6111 & 4 & 2 \\
\hline sec 13-05 & 120.0739 & 23.6148 & 3 & 3 \\
\hline sec 13.75 & 120.0709 & 23.6167 & 54 & 1 \\
\hline $\sec 13.10$ & 120.0681 & 23.6172 & 2 & 1 \\
\hline $\sec 13.15$ & 120.0488 & 23.6289 & 2 & 2 \\
\hline $\sec 13.20$ & 120.0429 & 23.6322 & 16 & 4 \\
\hline $\sec 13.30$ & 120.0361 & 23.6368 & 1 & 3 \\
\hline $\sec 13 . \mathrm{H}$ & 120.1294 & 23.5877 & 1 & 2 \\
\hline $\sec 13 . \mathrm{M}$ & 120.1229 & 23.5906 & 1 & 1 \\
\hline $\sec 13 . \mathrm{L}$ & 120.1187 & 23.5951 & 1 & 1 \\
\hline $\sec 14.01$ & 120.1086 & 23.5590 & 2 & 2 \\
\hline $\sec 14.03$ & 120.1061 & 23.5621 & 1 & 1 \\
\hline $\sec 14.05$ & 120.1034 & 23.5642 & 1 & 2 \\
\hline sec $14-75$ & 120.0947 & 23.5680 & 3 & 2 \\
\hline $\sec 14,10$ & 120.0562 & 23.5876 & 1 & 2 \\
\hline $\sec 14.15$ & 120.0420 & 23.6005 & 1 & 2 \\
\hline sec $14-20$ & 120.0349 & 23.6051 & 6 & 1 \\
\hline $\sec 14.30$ & 120.0205 & 23.6115 & 1 & 2 \\
\hline $\sec 15.01$ & 120.0839 & 23.5344 & 1 & 1 \\
\hline sec 15.03 & 120.0808 & 23.5350 & 3 & 3 \\
\hline $\sec 15-05$ & 120.0787 & 23.5358 & 6 & 3 \\
\hline sec 15,75 & 120.0742 & 23.5384 & 37 & 23 \\
\hline
\end{tabular}

\begin{tabular}{|c|c|c|c|c|}
\hline Sta. & long. (oE) & lat. $(\mathrm{oN})$ & 96-Mud\% & 97-Mud\% \\
\hline sec 15.10 & 120.0674 & 23.5448 & 69 & 47 \\
\hline sec $15-15$ & 120.0358 & 23.5756 & 5 & 33 \\
\hline $\sec 15.20$ & 120.0247 & 23.5807 & 26 & 53 \\
\hline sec 15.30 & 119.9850 & 23.6066 & 2 & 2 \\
\hline $\sec 16.01$ & 120.0693 & 23.5191 & 2 & 3 \\
\hline $\sec 16-03$ & 120.0674 & 23.5208 & 3 & 4 \\
\hline $\sec 16.05$ & 120.0650 & 23.5212 & 59 & 6 \\
\hline $\sec 16-75$ & 120.0636 & 23.5236 & 7 & 2 \\
\hline $\sec 16-10$ & 120.0574 & 23.5270 & 72 & 24 \\
\hline sec $16-15$ & 120.0366 & 23.5405 & 3 & 5 \\
\hline $\sec 16-20$ & 119.9989 & 23.5631 & 2 & 3 \\
\hline $\sec 16.30$ & 119.9775 & 23.5776 & 4 & 2 \\
\hline $\sec 17.01$ & 120.0494 & 23.5000 & 2 & 1 \\
\hline $\sec 17.03$ & 120.0485 & 23.5007 & 1 & 1 \\
\hline $\sec 17.05$ & 120.0453 & 23.5017 & 2 & 1 \\
\hline $\sec 17.75$ & 120.0417 & 23.5038 & 4 & 2 \\
\hline $\sec 17.10$ & 120.0377 & 23.5068 & 3 & 3 \\
\hline $\sec 17.15$ & 120.0234 & 23.5143 & 72 & 7 \\
\hline sec 17.20 & 119.9888 & 23.5327 & 3 & 2 \\
\hline $\sec 17.30$ & 119.9764 & 23.5409 & 4 & 2 \\
\hline $\sec 18.01$ & 120.0245 & 23.4816 & 1 & 1 \\
\hline $\sec 18.03$ & 120.0228 & 23.4830 & 1 & 2 \\
\hline $\sec 18.05$ & 120.0200 & 23.4838 & 2 & 2 \\
\hline $\sec 18.75$ & 120.0182 & 23.4855 & 2 & 1 \\
\hline $\sec 18.10$ & 120.0168 & 23.4866 & 4 & 1 \\
\hline $\sec 18.15$ & 120.0100 & 23.4897 & 5 & 1 \\
\hline $\sec 18.20$ & 119.9846 & 23.5057 & 2 & 1 \\
\hline $\sec 18-30$ & 119.9741 & 23.5127 & 5 & 1 \\
\hline $\sec 19.01$ & 119.9911 & 23.4510 & 2 & 1 \\
\hline $\sec 19.03$ & 119.9906 & 23.4532 & 1 & 1 \\
\hline $\sec 19.05$ & 119.9898 & 23.4556 & 1 & 1 \\
\hline $\sec 19.75$ & 119.9816 & 23.4652 & 2 & 2 \\
\hline $\sec 19.10$ & 119.9777 & 23.4676 & 1 & 1 \\
\hline $\sec 19.15$ & 119.9751 & 23.4696 & 1 & 1 \\
\hline $\sec 19-20$ & 119.9724 & 23.4756 & 1 & 1 \\
\hline $\sec 19-30$ & 119.9705 & 23.4776 & 16 & 1 \\
\hline $\sec 20.01$ & 120.0068 & 23.4394 & 1 & 1 \\
\hline $\sec 20.03$ & 120.0040 & 23.4369 & 1 & 2 \\
\hline $\sec 20.05$ & 119.9969 & 23.4350 & 1 & 1 \\
\hline $\sec 20.75$ & 119.9927 & 23.4341 & 1 & 1 \\
\hline
\end{tabular}


Appendix 2. (Continued)

\begin{tabular}{ccccc}
\hline Sta. & long. (oE) & lat. (oN) & 96-Mud\% & 97-Mud\% \\
\hline $\sec 20-10$ & 119.9920 & 23.4341 & 2 & 2 \\
$\sec 20.15$ & 119.9893 & 23.4328 & 3 & 2 \\
$\sec 20.20$ & 119.9869 & 23.4315 & 2 & 2 \\
$\sec 20.30$ & 119.9850 & 23.4307 & 45 & 3 \\
\hline
\end{tabular}

